OPEN ACCESS

Edited by:

Robin Mesnage,

King's College London,

United Kingdom

Reviewed by:

Jennifer Gallagher,

West Virginia University, United States

Oliana Carnevali,

Marche Polytechnic University, Italy

${ }^{*}$ Correspondence:

María Mercedes Milesi mmilesi@fbcb.unl.edu.ar

Specialty section: This article was submitted to Translational Endocrinology, a section of the journal

Frontiers in Endocrinology

Received: 26 February 2021 Accepted: 14 June 2021

Published: 07 July 2021

Citation:

Milesi MM, Lorenz V, Durando M, Rossetti MF and Varayoud J (2021)

Glyphosate Herbicide:

Reproductive Outcomes and

Multigenerational Effects.

Front. Endocrinol. 12:672532. doi: 10.3389/fendo.2021.672532

\section{Glyphosate Herbicide: Reproductive Outcomes and Multigenerational Effects}

\author{
María Mercedes Milesi ${ }^{1,2^{*}}$, Virginia Lorenz ${ }^{1}$, Milena Durando ${ }^{1,2}$, \\ María Florencia Rossetti ${ }^{1,3}$ and Jorgelina Varayoud ${ }^{1,2}$
}

\begin{abstract}
1 Instituto de Salud y Ambiente del Litoral (ISAL), Facultad de Bioquímica y Ciencias Biológicas, Universidad Nacional del Litoral (UNL) - Consejo Nacional de Investigaciones Cientificas y Técnicas (CONICET), Santa Fe, Argentina, ${ }^{2}$ Cátedra de Fisiología Humana, Facultad de Bioquímica y Ciencias Biológicas, Universidad Nacional del Litoral (UNL), Santa Fe, Argentina, ${ }^{3}$ Departamento de Bioquímica Clínica y Cuantitativa, Facultad de Bioquímica y Ciencias Biológicas, Universidad Nacional del Litoral (UNL), Santa Fe, Argentina
\end{abstract}

Glyphosate base herbicides (GBHs) are the most widely applied pesticides in the world and are mainly used in association with $\mathrm{GBH}$-tolerant crop varieties. Indiscriminate and negligent use of GBHs has promoted the emergence of glyphosate resistant weeds, and consequently the rise in the use of these herbicides. Glyphosate, the active ingredient of all $\mathrm{GBH}$, is combined with other chemicals known as co-formulants that enhance the herbicide action. Nowadays, the safety of glyphosate and its formulations remain to be a controversial issue, as evidence is not conclusive whether the adverse effects are caused by GBH or glyphosate, and little is known about the contribution of co-formulants to the toxicity of herbicides. Currently, alarmingly increased levels of glyphosate have been detected in different environmental matrixes and in foodstuff, becoming an issue of social concern. Some in vitro and in vivo studies have shown that glyphosate and its formulations exhibit estrogen-like properties, and growing evidence has indicated they may disrupt normal endocrine function, with adverse consequences for reproductive health. Moreover, multigenerational effects have been reported and epigenetic mechanisms have been proved to be involved in the alterations induced by the herbicide. In this review, we provide an overview of: i) the routes and levels of human exposure to GBHs, ii) the potential estrogenic effects of glyphosate and GBHs in cell culture and animal models, iii) their long-term effects on female fertility and mechanisms of action, and iv) the consequences on health of successive generations.

Keywords: glyphosate, glyphosate-based herbicides, estrogenic effects, female fertility, adverse reproductive outcomes, implantation failures, maternal exposure, multigenerational effects

\footnotetext{
Abbreviations: ADI, acceptable daily intake; AMPA, aminomethylphosphonic acid; ASD, autism spectrum disorder; CLs, corpora lutea; DMRs, DNA methylation regions; E2, 17ß-estradiol; EFSA, European Food Safety Authority; EPSPS, 5-enolpyruvylshikimate-3-phosphate synthase; ER $\alpha$, estrogen receptor alpha; ERE, estrogen response element; ERs, estrogen receptors; GBHs, glyphosate-based herbicides; GD, gestational day; Gly, glyphosate (active ingredient); H3K9me3, histone H3 lysine 9 trimethylation; HEK, human embryonic kidney; Hoxa10, Homeobox A10; ip, intraperitoneal; Lif, Leukemia inhibitory factor; MRLs, maximum residue limits; OR, odds ratio; PND, postnatal day; PTMs, histone posttranslational modifications; RfD, reference dose.
} 


\section{INTRODUCTION}

Since the genetic engineering revolution applied to agricultural crops two decades ago, area destined to genetic modified crops tolerant to herbicides have dramatically extended around the world, representing almost $90 \%$ of the farmlands. Most of these areas have been covered by glyphosate-tolerant crops, which triggered an increase in the use of glyphosate-based herbicides (GBHs) $(1,2)$. In addition to that, the annual global production of GBH formulations was estimated to be about one million tons (3). Particularly, in Argentina, one of the main producing countries of glyphosate tolerant crops (4), the marketing of GBHs reached nearly 200,000 tons in 2012, which represented $80 \%$ of total commercialized herbicides (5). Moreover, GBHs are non-selective, systemic, post-emergence herbicides (6) used for weed control on woody and herbaceous crops, but also for the maintenance of areas not used for agriculture, such as public, industrial spaces, in embankments, roadsides, homes and gardens (7). Therefore, due to the massive use and the variety of applications, GBHs have become the most widely applied pesticides worldwide (2).

Glyphosate [N-(phosphonomethyl) glycine], the active principle of GBHs, targets the enzyme 5-enolpyruvylshikimate3-phosphate synthase (EPSPS) of the shikimate pathway, a metabolic route for the biosynthesis of aromatic compounds in plants and microorganisms (8). The EPSPS converts shikimate3-phosphate to 5-enolpyruvylshikimate-3-phosphate, leading then to the biosynthesis of chorismate. Chorismate is the precursor of tyrosine, phenylalanine and tryptophan, but also of secondary metabolites, including ubiquinone, menaquinone, lignans, tannins, and flavonoids (9).

Glyphosate and its main metabolite, the aminomethylphosphonic acid (AMPA), are considered as 'least toxic' (category IV) substrates for mammals by the regulatory agencies, based on toxicity data, low environmental persistence, and the mechanism of action which is supposed to be confined to soil microbial and plants. Despite their apparent safety, recent evidence indicates that the mammal gut microbiome could be influenced by glyphosate. In this sense, some studies investigated the effects of glyphosate in microbiome of rats (10-12), cows (13) and pigs (14). Importantly, recent findings from Mesnage et al. (15) demonstrated that glyphosate treatment resulted in higher levels of intermediates of the shikimate pathway in the ceca, suggesting inhibition of EPSPS in the rat cecum microbiome. Although the rat gut microbiome is different from that of humans, epidemiological studies will be necessary to analyze whether environmental doses of glyphosate could disrupt gut microbiome metabolism. On the other hand, evidence has shown long half-lives depending on soil properties and environmental conditions, and harmful effect on human, animal and ecosystem health (16). This scenario is further aggravated whether one take into account the indiscriminate and negligent use of GBHs, which promoted the emergence of glyphosate resistant weeds, and consequently, the rise in the use of these herbicides and others to control them $(17,18)$. In this context, alarming levels of contamination exist, which is evidence by the detection of glyphosate and AMPA in different environmental matrixes such as surface waters (19), groundwaters and open-reservoir tank waters
(20), rainwaters and soil (21), dust (22) and air (23). Biomonitoring studies have also suggested that humans are likely to be exposed to glyphosate through drinking water (24) and foodstuff such as soy-based infant formula (25) and soy sauce (26). Environmental and food contamination by glyphosate have raised concern about the health effects on humans and non-target organisms because of potential chronic exposure with social consequences.

GBH formulations are constituted by other chemicals in addition to glyphosate, named as "inert ingredients" which enhance herbicide action by facilitating penetration into plant tissues. The chemical composition of these formulations is considered as confidential business information, so that, to date, little is known about the contribution of co-formulants to the toxicity of herbicides (27). Nowadays, the safety of glyphosate and its formulations remain to be a controversial issue, as evidence is not conclusive whether the adverse effects are caused by GBH or glyphosate alone. While some studies have shown that formulations are more toxic than the active ingredient (28-30), other works found similar adverse effects when exposed to glyphosate or GBH (31), or even stronger toxic effects of glyphosate compared to GBH in the short term (32). Probably, this controversy arises because of differences in composition between the brand names of GBH formulations, which highlight the importance of conducting not only comparative studies between the GBHs and the active principle, but also assaying a wide range of commercial formulations.

Growing evidence from both in vitro and in vivo studies has indicated that glyphosate and its commercial formulations may disrupt normal endocrine function, with effects on reproductive development and detrimental consequences on reproduction. The observed effects were diverse and some include hormonal imbalance (31-33), proliferation/mitotic index alterations $(33,34)$, deregulation of proteins and genes involved in endocrine pathways $(31,34,35)$, oxidative stress $(36)$, as well as, epigenetic disruption such as, alteration in DNA methylation levels and/or histone posttranslational modifications (PTMs) (37). Importantly, some results indicate that glyphosate appears to cause multigenerational effects, which might be transmitted transgenerationally to future generations $(38,39)$.

Despite these findings, the Endocrine Disruptor Screening Program lead by the United States Environmental Protection Agency (40) and later, the European Food Safety Authority (EFSA) (41) resolved that there was not sufficient evidence to support endocrine disrupting properties of glyphosate, turning this issue in another topic of conflict and scientific debate.

This review provides an overview of the routes of human exposure, the potential estrogenic effects of glyphosate and GBHs, their long-term effects on female fertility and mechanisms of action, and finally, the consequences on health of successive generations.

\section{ROUTES AND LEVELS OF HUMAN EXPOSURE TO GBHs}

Current studies on pesticides indicate that human exposure can occur through occupational use or proximity to areas with agricultural activity. However with the introduction of 
transgenic crops tolerant to agrochemicals, pesticide uses increased significantly and diet became one of the main sources of exposure to them (42-44). In transgenic glyphosate-tolerant crops, glyphosate can be applied to the crop (post-emergence) to remove emerged weeds without crop damage. Two strategies have been successful in introducing glyphosate tolerance: a) expression of an insensitive form of the target enzyme, and b) detoxification of the glyphosate molecule. The first one is used in existing commercial glyphosatetolerant crops: the employment of a microbial or a mutated form of EPSPS that is not inhibited by glyphosate. The disadvantage of this approach is that glyphosate could remain and be accumulated in the plant (45).

In Argentina, glyphosate levels were found in the order of $\mathrm{mg} /$ $\mathrm{kg}$ in transgenic soybean seeds and plants in farmlands $(46,47)$
(Table 1). In 7 out of 11 samples of soybeans, the maximum residue limits (MRLs) for soybean of $20 \mathrm{mg} / \mathrm{kg}$ established by the European Commission were exceeded, as reported a non-peer reviewed study conducted by Testbiotech, a German financed independent organization (47). Later studies have shown that a variety of cereals grains (barley, oat, rye, wheat) (48), pulses (50) and related food $(25,49)$ reported detectable levels of glyphosate and/or AMPA (Table 1), however they agree that those residues are below the current MRLs and the acceptable daily intake (ADI) corresponding to $0.5 \mathrm{mg} / \mathrm{kg}$ bw/day according to the EFSA (55). A worrying finding was the determination of contaminated soy-based formulas for infants from different commercial brands in a study performed in Brazil during 2012-2017. The residues of glyphosate were from $0.03 \mathrm{mg} / \mathrm{kg}$ to $1.08 \mathrm{mg} / \mathrm{kg}$ and of AMPA

TABLE 1 | Glyphosate and AMPA concentrations in food, water and air.

\begin{tabular}{|c|c|c|c|c|c|c|}
\hline Matrixes & Area & Lab Method & LOD/LOQ & Glyphosate levels & AMPA levels & Reference \\
\hline \multicolumn{7}{|c|}{ Cereal, pulses and related food } \\
\hline Barley & Denmark & LC-MS/MS & LOD: 0.2 mg/kg & $<0.45 \mathrm{mg} / \mathrm{kg}$ & NR & $(48)$ \\
\hline Oat & & & & $<0.08 \mathrm{mg} / \mathrm{kg}$ & & \\
\hline Rye & & & & $<0.04 \mathrm{mg} / \mathrm{kg}$ & & \\
\hline Wheat & & & & $<0.13 \mathrm{mg} / \mathrm{kg}$ & & \\
\hline Bread & Switzerland & LC-MS/MS & LOQ: $0.0005-0.0025$ mg/kg & $\begin{array}{l}<0.001-0.0458 \\
\mathrm{mg} / \mathrm{kg}\end{array}$ & $<0.0025 \mathrm{mg} / \mathrm{kg}$ & (49) \\
\hline Breakfast cereal & & & & $\begin{array}{c}<0.001-0.291 \mathrm{mg} / \\
\mathrm{kg}\end{array}$ & $\begin{array}{c}<0.0025-0.010 \\
\mathrm{mg} / \mathrm{kg}\end{array}$ & \\
\hline GM Soybean Leaves/stems & Argentina & HPLC & LOD: 0.2 mg/kg, & $1.9-4.4 \mathrm{mg} / \mathrm{kg}$ & $1.9-4.4 \mathrm{mg} / \mathrm{kg}$ & $(46)$ \\
\hline GM Soybean Grains & & & LOQ: 0.15 mg/kg & $0.1-1.8 \mathrm{mg} / \mathrm{kg}$ & & \\
\hline Whole GM soybeans & USA & HPLC-FLD & NR & $0.4-8.8 \mathrm{mg} / \mathrm{kg}$ & $0.7-10.0 \mathrm{mg} / \mathrm{kg}$ & $(50)$ \\
\hline GM soybeans grains & Argentina & HPLC & NR & $5.3-25.8 \mathrm{mg} / \mathrm{kg}$ & $<33.8 \mathrm{mg} / \mathrm{kg}$ & $(47)$ \\
\hline Soy-based infant formula & Brazil & HPLC-FLD & LOQ: $0.02 \mathrm{mg} / \mathrm{kg}$ & $0.0 .3-1.08 \mathrm{mg} / \mathrm{kg}$ & $0.02-0.17 \mathrm{mg} / \mathrm{kg}$ & (25) \\
\hline \multicolumn{7}{|c|}{ Water bodies (rivers, lakes, tributaries) } \\
\hline Surface water & Canada & $\begin{array}{l}\text { UHPLC- } \\
\text { HRMS }\end{array}$ & 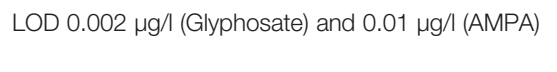 & $<0.002-3 \mu \mathrm{g} / \mathrm{l}$ & $<0.010-0.656 \mu \mathrm{g} / \mathrm{l}$ & $(19)$ \\
\hline Water & Argentina & HPLC-MS & NR & $<0.3 \mu \mathrm{g} / \mathrm{l}$ & $<0.7 \mu g / l$ & $(51)$ \\
\hline SPM & & & & $<0.04 \mu \mathrm{g} / \mathrm{l}$ & $<0.21 \mu \mathrm{g} / \mathrm{l}$ & \\
\hline Sediments & & & & $<3.004 \mathrm{mg} / \mathrm{kg}$ & $<5.374 \mathrm{mg} / \mathrm{kg}$ & \\
\hline Water & Argentina & HPLC-MS & NR & $1.25-4.52 \mu \mathrm{g} / \mathrm{l}$ & $0.77-0.9 \mu \mathrm{g} / \mathrm{l}$ & $(52)$ \\
\hline SPM & & & & $0.04-0.13 \mu g / l$ & $0.06 \mu \mathrm{g} / \mathrm{l}$ & \\
\hline Sediments & & & & $\begin{array}{l}0.004-0.020 \mathrm{mg} / \\
\mathrm{kg}\end{array}$ & $\begin{array}{l}0.012-0.032 \mathrm{mg} / \\
\mathrm{kg}\end{array}$ & \\
\hline Groundwater & Argentina & UHPLC-MS/ & 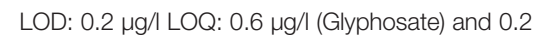 & $0.6-11.3 \mu \mathrm{g} / \mathrm{l}$ & $0.2-6.5 \mu \mathrm{g} / \mathrm{l}$ & $(20)$ \\
\hline Drinking tank water & & MS & $\mu g / l(A M P A)$ & $0.6-21.2 \mu \mathrm{g} / \mathrm{l}$ & $0.2-4.2 \mu \mathrm{g} / \mathrm{l}$ & \\
\hline Surface water & Sri Lanka & LC-MS & LOD: $0.1 \mu \mathrm{g} / \mathrm{l}$ & $28-45 \mu g / l$ & $<1 \mu g / l$ & (53) \\
\hline Groundwater & & & LOQ: $0.1 \mu \mathrm{g} / \mathrm{l}$ & $1-4 \mu g / l$ & $<11 \mu \mathrm{g} / \mathrm{l}$ & \\
\hline Sediments & & & & $\begin{array}{l}0.085-1.011 \mathrm{mg} / \\
\mathrm{kg}\end{array}$ & $<0.015 \mathrm{mg} / \mathrm{kg}$ & \\
\hline Surface water & Mexico & ELISA & LOD: $0.05 \mu \mathrm{g} / \mathrm{l}$ & 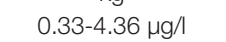 & NR & (54) \\
\hline Groundwater & & & & $0.26-3.17 \mu g / l$ & & \\
\hline Bottle water & & & & $<0.05 \mu \mathrm{g} / \mathrm{l}$ & & \\
\hline Runoff water & & & & $0.11-0.17 \mu g / l$ & & \\
\hline Groundwater & Mexico & ELISA & LOD: $0.05 \mu \mathrm{g} / \mathrm{l}$ & $0.44-1.41 \mu \mathrm{g} / \mathrm{l}$ & NR & $(24)$ \\
\hline Drinking water & & & LOQ: $0.13 \mu \mathrm{g} / \mathrm{l}$ & $0.35-0.65 \mu \mathrm{g} / \mathrm{l}$ & & \\
\hline Rain water & Argentina & $\begin{array}{l}\text { UHPLC-MS/ } \\
\text { MS }\end{array}$ & LOD: $0.25 \mu \mathrm{g} / \mathrm{l}$ & $0.5-2 \mu \mathrm{g} / \mathrm{l}$ & $1.5-7 \mu g / l$ & (9) \\
\hline Rain water & Argentina & HPLC-MS & LOD: $0.5 \mu \mathrm{g} / \mathrm{LOQ}: 1 \mu \mathrm{g} / \mathrm{l}$ & $0.5-67.28 \mu \mathrm{g} / \mathrm{l}$ & $0.75-7.91 \mu \mathrm{g} / \mathrm{l}$ & (51) \\
\hline \multicolumn{7}{|l|}{ Air } \\
\hline $\begin{array}{l}\text { Respirable dust of } \\
\text { agricultural soil }\end{array}$ & Argentina & UPLC & $\begin{array}{c}\text { LOD: } 0.36 \mu \mathrm{g} / \mathrm{l} \text { (Glyphosate) and } 0.41 \mu \mathrm{g} / \mathrm{I}(\mathrm{AMPA}) \\
\text { LOQ } 1.19 \mu \mathrm{g} / \mathrm{l} \text { (Glyphosate) and } 1.6 \mu \mathrm{g} / \mathrm{l} \text { (AMPA) }\end{array}$ & $11.0-19.5 \mu \mathrm{g} / \mathrm{l}$ & $520-750 \mu \mathrm{g} / \mathrm{l}$ & $(52)$ \\
\hline
\end{tabular}

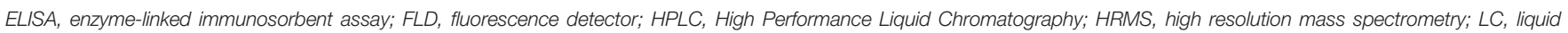

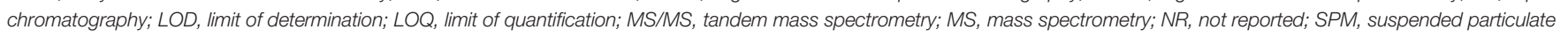
matter; UHPLC, Ultra High Performance Liquid Chromatography; UPLC, Ultra Performance Liquid Chromatography. 
were from $0.02 \mathrm{mg} / \mathrm{kg}$ to $0.17 \mathrm{mg} / \mathrm{kg}$ (25). According to Brazilian regulation, MRLs for this kind of product should be in line with the soybean raw material, which is $10 \mathrm{mg} / \mathrm{kg}$ (56); while the European Community establishes lower MRLs in cereal-based food and baby food for infants and young children of $0.01 \mathrm{mg} / \mathrm{kg}$ total (57). This example denotes great discrepancies between government institutions in relation to tolerable residues values in food. Data on the ingestion of GBH residues through foodstuffs still needs to be collected to continue monitoring the safety of various foods.

In regions with high agricultural activity, glyphosate and its mains metabolite (AMPA) have been detected with high frequency in sediments and surface waters from rivers and lakes $(19,51,52)$; and also, in groundwaters and open-reservoir tank waters $(20,53,54)$ (Table 1). Water resources can result contaminated by glyphosate and AMPA mainly due to the contribution of rainfall and surface runoff and to a lesser extent, by subsurface leaching or accidental spills, which might affect the ground and surface water deteriorating the drinking water quality as reported by Rendón-von Osten \& Dzul-Caamal (24) in Mexico (Table 1). The presence of glyphosate in groundwater and bottled drinking water in this work (highest mean level $0.65 \mu \mathrm{g} / \mathrm{l}$ ) indicated the excessive use of glyphosate in the agricultural communities studied (24). Regarding drinking water quality standards, each country has its own requirement of glyphosate residues. For instance, the maximum contaminant level for glyphosate is $280 \mu \mathrm{g} / \mathrm{l}$ in Canada and Argentina, $1000 \mu \mathrm{g} / \mathrm{l}$ in Australia, $700 \mu \mathrm{g} / \mathrm{l}$ in the US (58) and $0.1 \mu \mathrm{g} / \mathrm{l}$ in European Union (59). The differences between countries are due to the legislation on the use of genetic modified organisms and the number of hectares where this herbicide is applied (60). It should be noted that in a study performed in Argentina, glyphosate and AMPA have been identified at concentrations above the maximum permitted by the European Union in most of the rainwater samples analyzed (21). This information evidence the ubiquitous presence of glyphosate in water bodies and the potential exposure to glyphosate residues through dermal contact or ingestion.

Also, the presence of glyphosate in water resources might impact to a wide-range of non-target aquatic organisms. The toxic effects of glyphosate and $\mathrm{GBH}$ formulations have been extensively reported on algae, invertebrates and vertebrates from marine and river environments as evidenced by reviews on this topic $(61,62)$. It should be noted that several works revised by Matozzo's review (62) showed that the herbicide can affect biological responses after chronic exposure in marine species at low concentrations (in the order of magnitude of $\mu \mathrm{g} / \mathrm{l}$ ). In addition, an interesting work which carried out a hazard assessment for glyphosate in a river from Argentina indicated that aquatic and benthic organisms are at risk in the areas of intensive agricultural activity (63).

Another route of exposure could be via inhalation through contaminated respirable dust. Higher amounts of glyphosate $(11.0-19.5 \mu \mathrm{g} / \mathrm{l})$ and AMPA $(520-750 \mu \mathrm{g} / \mathrm{l})$ were detected in the respirable dust than in the sources of emission (bulk soil and aggregate-size fractions) of agricultural soil of the central region of Argentina, after 12 months from the last application of the herbicide (22) (Table 1). In addition, a more recent work proposed that atmospheric deposition of glyphosate through rainfall might constitute a source of exposure of the population to this pollutant from the air, and consequently, it suggested the importance of monitor the quality of the air in Argentina (64).

The study of the toxicokinetics of glyphosate represents a crucial issue for the assessment of human health risk. The more recently work addressing this question was performed by Anadón et al. (65) in male Wistar rats. Authors reported that glyphosate was slowly and poorly absorbed through the gastrointestinal tract after oral administration of a single dose of $400 \mathrm{mg}$ of glyphosate $/ \mathrm{kg}$; and the estimated oral bioavailability was approximately $23 \%$. The elimination half-life of glyphosate was $14.38 \mathrm{~h}$, and authors suggested that based on the apparent volume of distribution, glyphosate easily penetrated tissues (65). Other study analyzing the tissue distribution of glyphosate indicated bone, kidney, and liver as target tissues, among others (66). However, more toxicokinetic studies are needed to increase knowledge about the distribution fate of glyphosate in different tissues, organs and biological fluids, in order to predict whether glyphosate bioaccumulates in the body. Studies in rats, assessing a single oral administration of $\left({ }^{14} \mathrm{C}\right)$ glyphosate, showed that this compound is poorly metabolized and that is rapidly excreted unchanged in the urine (20-30\%) and feces (70$80 \%)(67-70)$. Metabolite analysis showed that AMPA was the only breakdown product detected $(65,71)$. Animal studies and acute ingestion cases in humans have described that glyphosate orally absorbed is metabolized to AMPA in a very low percentage $(<1 \%)(72,73)$. The human biological half-life of glyphosate was estimated between $3 \frac{1}{2}$ and $14 \frac{1}{2}$ hours (74), indicating its rapid elimination. For this reason, urine levels of glyphosate provide a measure of recent occupational (agricultural practices and $\mathrm{GBH}$ manufacture) or non-occupational (aerosols, diet and drinking water) exposure to GBHs (12). Different works have detected higher levels of glyphosate in urine samples from people living near agricultural fields in comparison to those who live in urban areas $(24,75)$ (Table 2). However, other authors were unable to find differences in the levels of glyphosate or AMPA in relation to the residential environment in children and adolescents from rural regions (76). Gillezeau et al. (82), revised the literature to document human exposure to glyphosate among populations in different settings. They reported that the geometric mean for urinary glyphosate levels in occupationally exposed subjects ranged from 0.26 to $73.5 \mu \mathrm{g} / \mathrm{l}$, and the environmental exposure urinary levels ranged from 0.16 to $7.6 \mu \mathrm{g} / \mathrm{l}$ [(for further details, see in review 82)]. On the other hand, a recent work evaluated the urinary levels of glyphosate and AMPA in Chinese workers involved in glyphosate production (i.e exposed to the herbicide at work) and detected higher concentrations of glyphosate. For glyphosate, the median was of $292 \mu \mathrm{g} / \mathrm{l}$ (range $20-17,202 \mu \mathrm{g} / \mathrm{l}$ ) and for AMPA, the median was of $68 \mu \mathrm{g} / \mathrm{l}$ (range 10-2,730 $\mu \mathrm{g} / \mathrm{l}$ ). Furthermore, urinary concentration of glyphosate and AMPA (internal dose) was correlated with the amount of glyphosate in the air of workplace (considered as the external dose) which was $<0.02 \mathrm{mg} / \mathrm{m}^{3}-34.58 \mathrm{mg} / \mathrm{m}^{3}$ and is expressed as the time weighted 
average concentration of glyphosate in the air, which could reflect the actual exposure of workers (77). Despite all the above information, the number of studies reporting urinary levels of glyphosate and AMPA are still limited taking into account the extent in the usage of GBHs around the world. More studies are needed to expand the geographic regions analyzed and thus better understand the possible sources of exposure in each context.

In vitro and ex vivo human placental perfusion experiments have shown that glyphosate is able to cross the placenta $(83,84)$. In addition to that, glyphosate levels have been detected not only in serum of pregnant women at childbirth $(0.2-189.1 \mu \mathrm{g} / \mathrm{l})$ but also in umbilical cord samples $(0.2-94.9 \mu \mathrm{g} / \mathrm{l})(78)$ which support the idea that glyphosate can reach the fetus (Table 2). Moreover, high frequency (more than 90\%) pregnant women were reported to have detectable levels of glyphosate in urine residing in rural and urban areas (75). Based on this data, the herbicide glyphosate could affect the mother and child during pregnancy. Regarding glyphosate exposure through breastfeeding, a nonpeer-reviewed report informed that glyphosate was present in 3 out of 10 breast milk samples ranging from 76 to $166 \mu \mathrm{g} / \mathrm{l}$ (79). Later, two studies found no evidence of transfer of glyphosate into milk. One of them reported that neither glyphosate nor AMPA were detected in breast milk, although lactating women had urine detectable levels of glyphosate and AMPA (80). Similar results were obtained by Steinborn et al. (81), who analyzed 114 breast milk samples from German women finding no detectable levels of glyphosate (Table 2). Further independent research is advisable to confirm this critical route of exposure using adequate sample size of the cohort and assessing other geographical contexts (occupational vs. environmental exposure).

As we have previously shown, the massive use of the herbicide and the possibility of finding it in multiple matrixes, including biological samples, led that many efforts have been invested in studying sensitive and low-time consuming methodologies to detect glyphosate and AMPA. In the last years, the most frequently used methodologies to detect these compounds were chromatography-mass spectrometry: liquid chromatography (LC) or high-performance liquid chromatography (HPLC) and gas chromatography (GC) coupled with tandem mass spectrometry (MS/MS) and enzyme-linked immunosorbent assay (ELISA). Also, other techniques of great interest such as electrochemical sensors and cell biosensor have been developed [for further details, see review (85)]. Nowadays, HPLC-MS/MS is considered the most suitable technique for the detection of phosphonic and amino acid type herbicides such as glyphosate at low concentrations (86). Furthermore, HPLC-MS/MS has higher recovery values when compared to GC-MS/MS (81). The particular physicochemical characteristics of glyphosate and AMPA (low volatility and high water solubility) make the detection of both at trace levels difficult, in addition to the need of using additional steps such as derivatization since the lack of chromophore or fluorophore groups (87). The limits of detection for the methodologies available have been decreased over time which have helped to improve the quality of data in relation to glyphosate levels to what humans and living organisms are exposed (88). For example, a recent work analyzing urine levels in Portuguese adults reported highly sensitive and low

TABLE 2 | Glyphosate and AMPA concentrations in human biological samples.

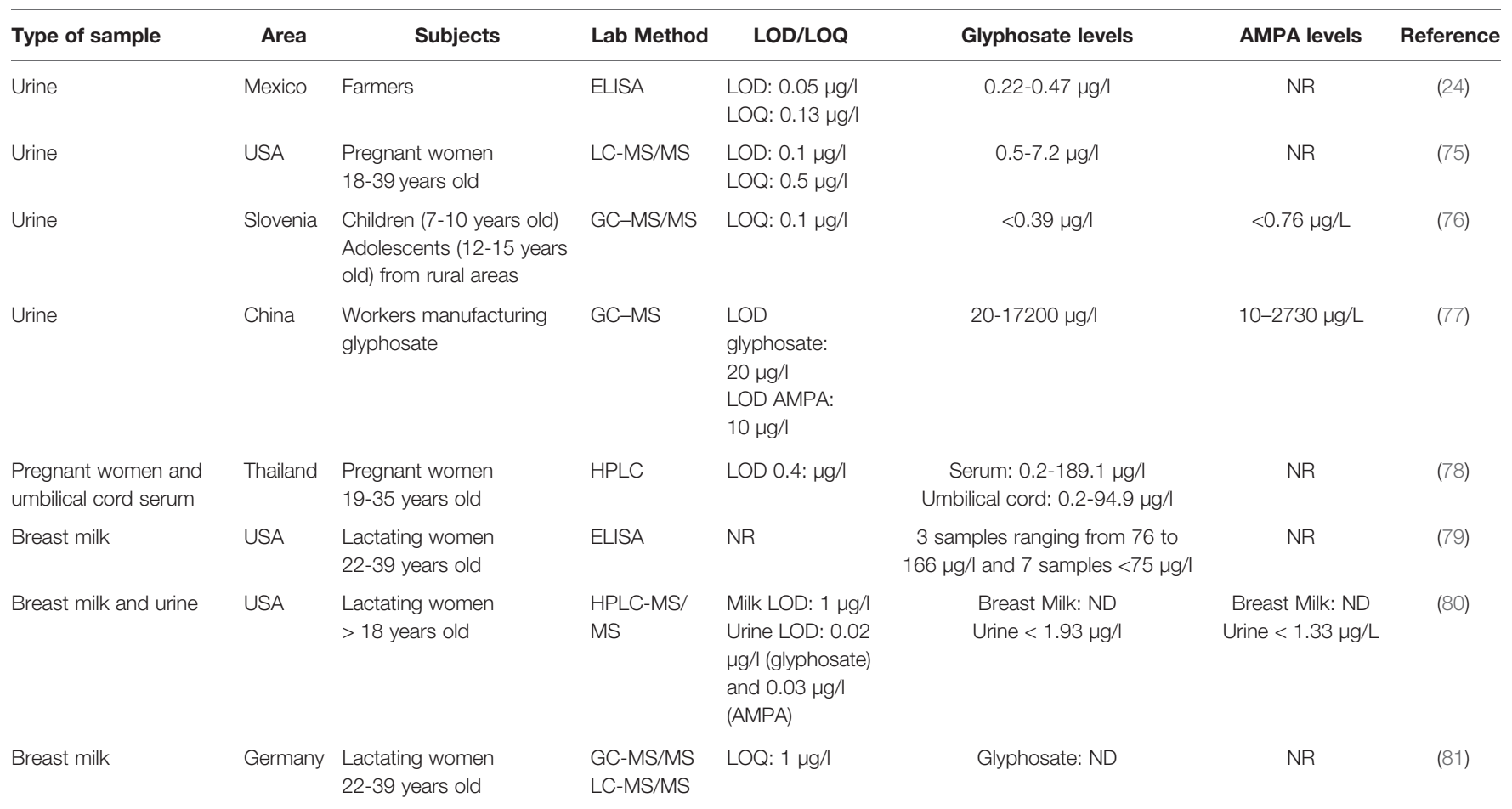

ELISA, enzyme-linked immunosorbent assay; GC, gas chromatography; HPLC, High Performance Liquid Chromatography; LC, liquid chromatography; LOD, limit of determination; LOQ, limit of quantification; MS/MS, tandem mass spectrometry; MS, mass spectrometry; ND, not detected; NR, not reported. 
limits of detection (LOD) for glyphosate of $0.02 \mu \mathrm{g} / \mathrm{l}$ and for AMPA of $0.013 \mu \mathrm{g} / \mathrm{l}$, with a limit of quantification (LOQ) for both of $0.05 \mu \mathrm{g} / \mathrm{l}$ applying HPLC-MS/MS (89). Regarding ELISA method, it has been proved to be sensitive since the LOD are better than GC-MS/MS, and even similar of those obtained by HPLC-MS/MS (90). The disadvantages of ELISA are the high limits of AMPA detection and the occurrence of false positives as a result of cross-reactivity with other organic contaminants (91). At the same time, it is considered a cost-effective method for routine analysis but commercial kits are relatively expensive (92). Researchers claim for the development of new approaches to detect glyphosate in a fast, easy and effective manner using a portable device for real time assays in the field (85). Tables 1 and 2 include the methods utilized, LOD and LOQ for different glyphosate determinations in food, environmental and biological samples. Monitoring of these matrixes to estimate the levels of human exposure to glyphosate, as well as, networking between institutions with the appropriate platforms or equipment to detect pesticides should be encouraged by governments.

\section{ESTROGENIC EFFECTS OF GLYPHOSATE AND GBHs IN CELL CULTURE AND ANIMAL MODELS}

Some environmental chemicals exhibit estrogen-like properties, acting directly by activating or inhibiting estrogen action, or indirectly by modulating its action and consequently, altering the normal regulatory function of the endocrine system (93). In this sense, several in vitro and in vivo studies have been performed to elucidate whether glyphosate and/or GBH are able to induce estrogenic effects.

Regarding in vitro studies, potential targets involved in the estrogenic pathway were evaluated in multiple cell lines, such as human placenta (94), human embryonic kidney (HEK)293 cells (95), bovine granulosa and theca cells $(33,96)$, human breast cancer cells $(97,98)$ and human endometrial carcinoma cells (99). The enzyme aromatase cytochrome P450 which converts androgens into estrogens and also, considered a limiting step for estrogen biosynthesis was assessed (100). This enzyme is implicated in several physiologic functions, including female and male gametogenesis, sex differentiation, reproduction and bone growth (101). Richard et al. (94), demonstrated that GBH decreased aromatase activity in association with a downregulation of its gene expression in human placental JEG3 cells working with concentrations lower than those used with agricultural purposes. In the same work, both glyphosate and GBH had an inhibitory effect on aromatase activity in human placental and equine testicular microsomes and proved to interact with the active site of the purified enzyme. Similarly, Benachour et al. (95), showed that both GBH and glyphosate inhibit aromatase activity in HEK 293 cells, placental-derived JEG3 cells, and extracts from human placenta and mammalian testis. Another potential target of glyphosate and $\mathrm{GBH}$ is the product of aromatase enzyme, the hormone estradiol (E2). Ovarian granulose cells were evaluated as they are the main source of E2 secretion. Some authors showed that glyphosate and GBH inhibit E2 secretion in granulose cells from farm animals (cows and swines) $(33,96,102)$. These results evidence that glyphosate and GBH disrupt aromatase expression and ovarian steroid production in vitro with potential negative consequences for the reproductive system, antagonizing estrogenic effects. Kiyama and Wada-Kiyama (93) listed in their review estrogenic chemicals that have exhibited contradictory results depending on the assay and concentration evaluated. Therefore, estrogenic compounds include chemicals that have not only estrogenic effects but also anti-estrogenic ones. Other researchers investigated estrogenic effects of glyphosate and GBHs on human breast cancer cells. Glyphosate induced the proliferation of T47D and MCF-7 cells, hormone-dependent human breast cancer cell lines; however, it failed to produce proliferation in MDA-MB231 cells, a hormone-independent human breast cancer cell $(97,98)$. These results allowed to suggest that estrogen receptor (ER) signaling may be involved in the glyphosate-induced proliferative effects. Later, when T47D cells were exposed to ICI 182,780 (Fulvestrant, the first steroidal 'pure' antioestrogens), the proliferative effects of both glyphosate and E2 were mitigated (97, 98). Additionally, glyphosate was seen to stimulate estrogen response element (ERE)-mediated transcription of a luciferase reporter gene and ICI 182,780 blocked the stimulatory effects (97, 98). Based on these results, glyphosate induce cell proliferation and ERE activation through ER. Thongprakaisanget al. (97), also found that glyphosate induces both ERs with different patterns. While $\mathrm{ER} \beta$ activation occurs in a rapid way, $\mathrm{ER} \alpha$ activation is slower but longer. Molecular dynamic simulations were used to evaluate and compare E2 and glyphosate binding energies to ER $\alpha$. This analysis showed that glyphosate binds at the active site of the receptor in a weak and unstable mode, which indicates that glyphosate is unlikely to activate ER $\alpha$ directly (98). It is known that estrogenic effects can be caused by an activation of ER in a ligand-independent manner. So, Mesnage et al. (98), proposed that glyphosate might increase ERE-luciferase reporter gene expression by a ligand-independent mechanism which could involve an interplay with cellular signaling pathways. More recently, a work from our lab studied whether glyphosate was able to cause similar effects as E2 on epithelialmesenchymal transition-related process by using the Ishikawa cell line (a human endometrial carcinoma cell line) (99). Glyphosate promoted cell migration and invasion, and down-regulated $\mathrm{E}$ cadherin mRNA expression in a similar way to E2. All the mentioned effects were reversed after treatment with ICI 182,780. Altogether, the results suggested that glyphosate could act via ERdependent pathway and most importantly, glyphosate might stimulate the estrogenic pathway in a tumoral microenvironment (99). Table 3 summarizes the most relevant results of mechanistic evidence of glyphosate and GBH estrogenic-like properties.

Among in vivo studies, in our laboratory we have explored estrogenicity of GBH using different experimental approaches $(103,104)$. The results showing in vivo estrogenic-like properties are summarized in Table 3. Firstly, Varayoud et al. (103) evaluated the potential estrogenic effects of a GBH formulation by a classical in vivo test, the uterotrophic assay. We used ovariectomized rats, which were subcutaneously injected with a 
$\mathrm{GBH}$ formulation in doses of $0.5,5$, or $50 \mathrm{mg}$ glyphosate/kg bw/ day or with an uterotrophic $\left(2.10^{-5} \mathrm{~g} \mathrm{E} 2 / \mathrm{kg} /\right.$ day $)$ or a nonuterotrophic $\left(2.10^{-7} \mathrm{~g}\right.$ E2 $/ \mathrm{kg} /$ day) dose of E2. The uterine wet weight, which is the hallmark of this assay, was not increased by $\mathrm{GBH}$ treatments as it was expected for an estrogenic compound. However, the herbicide altered estrogen-sensitive genes and ER protein expression in the uterus, similar to the effects of a nonuterotrophic dose of E2 (103). In a more recent work, we studied how neonatal exposure to $2 \mathrm{mg}$ glyphosate/ $\mathrm{kg}$ bw/day dose of a $\mathrm{GBH}$ in Wistar rats impacts on the uterus response to E2 later in life (104). Interestingly, our results showed that GBH exposure increased the sensitivity to E2 in ovariectomized rats, accompanied of histomorphological changes referenced as endometrial hyperplasia characterized by an increase of luminal epithelial height, high stromal nuclei density and proliferation (105). In addition to these morphological alterations, changes in molecules pointed out like E2-modulated targets and implicated in uterine E2 responsiveness were observed (104). Furthermore, several studies have reported deregulation of E2 levels, ER $\alpha$ protein and gene expression, and E2-dependent genes after $\mathrm{GBH}$ or glyphosate exposure in animal models $(31,35,36$, 106, 107).

The potency of estrogenic compounds is a complicated issue since the effects depend on the end point, receptor type, pathway, tissue, window of exposure, among others. As an example, Bisphenol A (BPA) sometimes is called as a "weak" estrogen because of its relatively weak binding/activation of the nuclear receptors compared to $\mathrm{E} 2$, although this is not always the case (108). However, when the non-genomic estrogenic activity of BPA was measured, it resulted comparable or more potent than E2 (108). In the case of Gly and GBH, in vitro studies show that both have estrogenic properties, which are weaker in comparison to $\mathrm{E} 2$ considering the present evidence. In addition, in vivo results show that estrogen pathway is a sensitive target of GBHs and that these herbicides might exacerbate the response to environmental estrogens. However, further in vitro and in vivo research is warranted to compare the estrogenic potency of glyphosate and its formulations in relation to E2 and other endocrine disruptor chemicals that have been defined as estrogenic compounds (such as BPA).

\section{ADVERSE REPRODUCTIVE OUTCOMES OF GLYPHOSATE AND ITS FORMULATIONS}

Infertility is estimated to affect up to $15 \%$ of couples worldwide (109), and remains an ongoing reproductive problem, despite advances in assisted reproductive techniques (110). Growing evidence has shown that lifestyle factors and exposure to polluting chemicals with endocrine disrupting properties

TABLE 3 | In vitro and in vivo assays showing estrogenic-like properties of glyphosate (Gly) and glyphosate-based herbicides (GBHs).

\begin{tabular}{|c|c|c|c|}
\hline Compound tested & Exposure type & Estrogenic-like effects & Reference \\
\hline
\end{tabular}

in vitro assays

Glyphosate (Gly)
Model: T47D cells (hormone-dependent human breast cancer cells) Exposure: $24 \mathrm{~h}$ Concentration: $169 \times 10^{-12}$ to $169 \times 10^{-6} \mathrm{~g} / \mathrm{l}$

-GBHs: Roundup ProBio, Glyphogan, Roundup Grand Travaux Plus, and Roundup Original DI -Glyphosate (Gly)

Glyphosate (Gly)

in vivo assays

$\mathrm{GBH}$

GBH: Roundup Full ॥
Model: T47D and MCF-7 cells (hormonedependent human breast cancer cells) Exposure: $24 \mathrm{~h}$ or 6 days (depend on the assay) Concentration: $10 \times 10^{-6}$ to $1,000,000 \times 10^{-6} \mathrm{~g} / \mathrm{l}$

Model: Ishikawa cells (human endometrial carcinoma cells)

Exposure: $24 \mathrm{~h}$

Concentration: $33.8 \times 10^{-6}$ and $338 \times 10^{-6} \mathrm{~g} / \mathrm{l}$

Model: adult ovariectomized female rat Exposure: for 3 consecutive days after ovariectomy through subcutaneous injection Dose: $0.5,5$ and $50 \mathrm{mg}$ Gly/kg/day Target organ: uterus

Model: ovariectomized female rat on postnatal day (PND)21

Exposure: on PND1, 3, 5, and 7 through subcutaneous injection + E2 implants from PND21 to PND60

Dose: 2 mg Gly/kg/day

Target organ: uterus
-Gly induced proliferation

-Gly induced estrogen response element transcriptional activity blocked by the estrogen antagonist ICl 182,780.

-Gly increased the expression of $E R \alpha$ and $E R \beta$

-Antagonist effect of Gly in presence of estradiol (E2)

-Gly induced proliferation

-Gly induced estrogen response element

transcriptional activity blocked by the estrogen

antagonist $\mathrm{ICl} 182,780$.

-Gly induced cell migration and invasion

-Gly decreased E-cadherin mRNA expression

-Gly effects were reversed by the estrogen antagonist

ICl 182,780

-GBH increased luminal epithelial height

- GBH decreased ER $\alpha$ mRNA levels

-GBH disrupted estrogen-responsive gene expression

-GBH increased luminal epithelial height -GBH increased E2-induced cell proliferation - $\mathrm{GBH}$ deregulated $\mathrm{ER} \alpha$ and $\mathrm{ER} \beta$ expression

-GBH enhanced the response to E2

GBH, Glyphosate-based herbicide; Gly, glyphosate (active ingredient); E2, 17 $\beta$-estradiol; ER $\alpha$, estrogen receptor alpha; ER 3 , estrogen receptor beta; PND, postnatal day. 
represent potential risks factors associated with alterations of the reproductive health, including subfertility/infertility $(111,112)$. In this sense, several epidemiological studies showed an association between environmental and/or occupational exposure to pesticides and male and female infertility and adverse pregnancy outcomes (113-119). As for GBHs, although they are the most widely used pesticides worldwide, to date, human studies addressing the effects on reproductive health are scarce. A retrospective study performed in a rural population from Ontario (Canada) showed that pre-conception exposure to glyphosate was associated with elevated risk of late abortions (120). In a more recent study, higher glyphosate urine levels were correlated with shortened gestational lengths in an Indiana cohort (USA) of pregnant women from rural and non-rural areas (75). In another work from Thailand, higher levels of glyphosate were detected in pregnant women who work in agriculture or live in families that work in agriculture (78).

Although more epidemiological data are necessary, growing evidence from animal studies has shown detrimental effects of glyphosate and GBHs on reproductive health at environmentally relevant doses, including pre- and post-implantation embryo losses $(31,34,121,122)$, fetal growth retardation and structural congenital anomalies (121-123). These findings are discussed in the following sections.

\section{Effects on Female Reproductive Performance}

Most in vivo studies that aimed at evaluating the effects of glyphosate and $\mathrm{GBH}$ s on female reproduction have been conducting using rodents as animal models. The first report showing female fertility failure by $\mathrm{GBH}$ exposure was published in our lab by Ingaramo et al. (34). In that work, we exposed female rats to a low dose of the herbicide, i.e. $2 \mathrm{mg}$ of glyphosate/ $\mathrm{kg}$ bw/day, which is in the order of magnitude of the currently reference dose (RfD) (1 mg of glyphosate/kg bw/day) according to EPA (124) and 4-fold higher than the ADI established by EFSA (125). GBH was administered on postnatal days (PND) 1 , 3, 5 and 7, by subcutaneous injections. On PND90, females were mated with males of proven fertility to evaluate the reproductive performance on gestational day (GD) 19. We found that although all GBH-exposed females became pregnant, neonatal exposure to the herbicide significantly increased the number of resorption sites leading to an increase in the rate of postimplantation embryo losses. It is important to highlight that neither the number of corpora lutea (CLs), nor the number of implantation sites were altered. In a later study, we investigated the effects on fertility of two doses of a GBH (i.e. $2 \mathrm{mg} / \mathrm{kg} /$ day and $200 \mathrm{mg} / \mathrm{kg} /$ day) applying a different experimental approach $(121,122)$. In this experiment, pregnant rats (F0) received the $\mathrm{GBH}$ through food, which is a more representative route of human exposure, from GD9 until weaning, and the reproductive performance was evaluated in sexual matured F1 females. Similar to our previous findings, no alterations in the pregnancy rate and number of CLs were found; however, no differences were detected in the number of resorption sites. Importantly, a significant lower number of implantation sites, in association with an increase of the rate of pre-implantation embryo losses were recorded for the higher $\mathrm{GBH}$ dose studied. We also observed an abnormal implantation pattern in both $\mathrm{GBH}$ exposed groups, characterized by unilateral pregnancies without alterations in the number of CLs from the ovary adjacent to the non-pregnant uterine horn. More recently, we performed two comparative studies led to evaluate the effects of $\mathrm{GBH}$ on fertility. One of them was performed to compare glyphosate alone $v s \mathrm{GBH}$, to analyze the possible differences between commercial formulation and pure glyphosate (31). Interestingly, in this work we detected 3-fold higher serum levels of glyphosate in the GBH-treated F0 dams in comparison with Gly-treated rats. On the other hand, Panzacchi et al. (126) quantified the levels of glyphosate in urine samples from F0 dam rats and their offspring which were exposed to a $\mathrm{GBH}$ formulation or Gly through drinking water. They found a tendency to detect higher levels of glyphosate in GBH-exposed animals. Based on this evidence, it might be proposed that coformulants, additives incorporated to $\mathrm{GBH}$ formulations, could alter the absorption and/or excretion of glyphosate increasing its levels in serum or urine. This study showed that both GBH and Gly cause an increase in the rate of pre-implantation embryo losses, suggesting that the active principle might be the main responsible for the effects observed (31). Despite the levels of glyphosate reached in serum were different between the treatments, both compounds induce similar deleterious effects. In the second study, we aimed to assess the effects of GBH in comparison with a mixture of commercial formulations of glyphosate and endosulfan (127). The pesticide mixture produced adverse reproductive effects that were similar to that induced by $\mathrm{GBH}$ alone, indicating a predominant effect of the herbicide (127). According to these results, we provided evidence which indicate that the deleterious effects are produced by the active ingredient glyphosate. In addition, we consider that it is necessary to increase information about the effects of mixtures of pesticides which represent more realistic scenarios to mimic the environmental exposure.

To our knowledge, only one report from other lab found adverse effects of $\mathrm{GBH}$ on female fertility when assessing F0 dams unlike our work in which we evaluated F1 dams (128). In that work, pregnant female rats were exposed to a sub-lethal dose of $\mathrm{GBH}$ alone $(500 \mathrm{mg} / \mathrm{kg})$ or in association with other herbicide ( $500 \mathrm{mg} / \mathrm{kg}$ of a $\mathrm{GBH}$ plus $50 \mathrm{mg} / \mathrm{kg}$ of Paraquat) administered by gavage during early pregnancy from GD1 to GD7, and the assessment of the reproductive capability was performed on the seventh day of pregnancy. The results showed that individual or combined exposure to herbicides decreased implantation sites and increased pre-implantation embryo losses. Authors also reported decrease in the ovary weight and in the total number of CLs (128). Although some studies have demonstrated that GBHs impaired ovarian function in vivo $(36,129)$, the consequences of these detrimental effects on fertility were not evaluated yet.

Overall, the reported effects on fertility differed between studies. Some of them are associated with increased postimplantation embryo losses (34) and others with increased 
pre-implantation embryo losses $(31,121,122,127,128)$. These differential effects could be probably due to differences in the experimental approaches, such as, administration routes (subcutaneous injections vs. diet or gavage treatment), window/ lengths of exposure (brief postnatal exposure vs. gestational/ lactational exposure), among other factors that might impact on the physiology of the exposed organism. Despite that, all these findings provide evidence that the active principle glyphosate, GBHs, or the herbicide being part of a pesticide mixture cause adverse effects on female reproductive capability.

\section{Hormonal, Molecular and Epigenetic Alterations Associated With Implantation Failures}

Our previous results showed that in utero and lactational exposure to Gly or GBH impairs female fertility by reducing the number of implanted embryos and increasing the rate of preimplantation embryo losses $(31,121,122)$. This section aims to integrate the knowledge available to date on the mechanisms that might explain the implantation failures, with focus on hormonal, molecular and epigenetic alterations, which might affect the uterine receptivity.

Embryo implantation is a complex process that requires the temporal interaction between developmentally competent blastocysts and a receptive uterus (130). Failure of the embryo to implant is a major cause of infertility, and is mainly associated with impaired uterine preparation to achieve the receptive stage (131). Uterine receptivity refers to the window of limited time in which the endometrium undergoes morphological, cellular and molecular changes conducive to blastocyst attachment, and subsequent pregnancy establishment (132). The set of these complex uterine changes, known as functional differentiation, is orchestrated by the ovarian hormones estrogen and progesterone. These hormones act primary via their nuclear receptors, progesterone receptor (isoforms $\mathrm{PR}-\mathrm{A}$ and $\mathrm{PR}-\mathrm{B}$ ) and estrogen receptor alpha $(\mathrm{ER} \alpha)$, to direct transcriptional pathways in the endometrium leading to the establishment of the "window of receptivity", i.e. the period in which the uterus is permissive to embryo implantation (132). Many hormoneregulated signaling pathways are involved in uterine receptivity; some of them include transcription factors, growth factors, cytokines, and diverse signaling molecules $(133,134)$.

In recent years, our work was focused on elucidating the mechanisms responsible for the implantation failures by Gly and $\mathrm{GBH}$ exposure. For that purpose, F1 females which were perinatally exposed to a low dose $(2 \mathrm{mg} / \mathrm{kg} /$ day $)$ of Gly or $\mathrm{GBH}$, became pregnant and hormonal and uterine targets were evaluated on GD5 (during the pre-implantation period). Higher serum levels of E2 along with increased uterine ER $\alpha$ expression were detected in Gly- and GBH-exposed females (31). It is well known that estrogen levels are critical in determining the window length of uterine receptivity for blastocyst implantation $(135,136)$. Low estrogen levels tend to extend the period of receptivity, while higher serum levels and/or ER $\alpha$ expression may close the window in advance, leading the uterus to a refractory state (135). Considering this information, our findings suggest that hormonal imbalance prompted by Gly and GBH might short the window of receptivity which lead to the decreased implantation rate.

As previously stated, several in vitro and in vivo studies have found ovarian dysfunction by Gly or GBH treatment. Some of the deleterious effects include: altered ovarian morphology, impaired folliculogenesis, disruption of aromatase activity (enzyme responsible for estrogen synthesis), hormonal imbalance, and increased oxidative stress, among others (33, $36,94,96,102,129,137)$. It is worthy to mention that although we did not assess the ovarian function, the ovulation rate and the CL "activation" were conserved in females perinatally exposed to Gly or GBH, as no changes were detected in the number of CLs (31, 121, 122). In accordance with these results, it has been reported that the sustained increase of E2 during the follicular phase did not affect oocyte and embryo quality but had detrimental effect on implantation and pregnancy (138).

To deeply understand the mechanisms involved in Gly- and $\mathrm{GBH}$-induced implantation failures, we analyzed the expression of hormone-responsive genes, which are essential for successful implantation. Two genes, the Homeobox A10 (Hoxa10) and the Leukemia inhibitory factor (Lif), were downregulated in the preimplantation uterus of females exposed to Gly and GBH (31). Hoxa10 is a transcription factor that plays a dual role; during embryogenesis Hoxa10 drives the development and patterning of the uterus, and at adulthood regulates uterine receptivity, implantation and subsequently endometrial decidualization (139). On the other hand, Lif is a pro-inflammatory cytokine belonging to the interleukin-6 family also required for implantation, which participate in both endometrial preparation and embryo attachment $(140,141)$. In this sense, gene targeting studies performed in mice have contributed to shed light on the importance of these genes for the success of the implantation process. It has been demonstrated that targeted mutation of either Hoxa10 or Lif in mice did not impair embryo viability but alter uterine differentiation at the receptive stage leading to implantation failures. Interestingly, embryos from Hoxa10 or Lif knockout females normally implant when transferred to wild-type surrogates, indicating that maternal uterine alterations are responsible for such effects (142-146). Under physiological conditions, maximal expression of both Hoxa10 and Lif occurs at the window of receptivity, which coincides with a peak in the E2 serum levels $(139,146)$. It was reported that although estrogen at physiological range stimulates Lif expression, an abnormal increase of this hormone induces an inhibition of Lif leading to defective implantation (147). These findings are in accordance with our results showing significantly higher E2 serum levels along with lower expression of Lif in the uterus of Gly and GBH-exposed females exhibiting lower implantation rates (31). Human clinical evidence further supports the requirement of HoxalO and Lif for uterine receptivity, based on the association between defective expression of both genes and recurrent implantation failures, infertility, and gynecological disorders including endometriosis, and polycystic ovary syndrome in women (148-152).

Some studies have evaluated the action of glyphosate or its formulations as possible endocrine disruptors. Many of them 
have found, as common outcomes, alterations in i) the E2 biosynthesis, ii) the levels of ER expression, iii) the signaling pathways or cellular events that are under the control of estrogens $(98,102,104)$. As we mention before, timely and normal E2 serum levels and/or ER $\alpha$ expression are crucial in determining the window of uterine receptivity and therefore the success of implantation. Based on this background, we proposed that alterations of $\mathrm{ER} \alpha$ gene expression could explain, at least in part, the effects of GBH on implantation. So that, we investigated whether the levels of expression of uterine ER $\alpha$ gene were altered, and whether epigenetic mechanisms could be involved in the disruption of implantation events (37). Previous reports have been proved that environmental exposure to polluting chemicals prompt epigenetic marks such as, DNA methylation, PTMs, and noncoding RNAs, leading to changes in gene transcription, and even to transgenerational inheritance of such epigenetic alterations (153). In our work, we found that perinatal exposure to $\mathrm{GBH}$ induces long-term epigenetic modifications in the $\mathrm{O}$ promoter of $\mathrm{ER} \alpha$ rat gene characterized by DNA hypomethylation, and alterations in PTMs (increase of histone $\mathrm{H} 4$ acetylation and histone $\mathrm{H} 3$ lysine 9 trimethylation (H3K9me3), and decrease of H3K27me3 (37). Altered methylation/acetylation pattern of ER $\alpha$ promoter regions have been found in different pathological conditions such as breast and colon cancer, uterine leiomyomas, and ovarian endometrioma (154-157). Our findings show that epigenetic disruption of the uterine $\mathrm{ER} \alpha$ gene could be linked to the GBH-induced implantation failures.

In the last years, there has been growing evidence showing that glyphosate and $\mathrm{GBH}$ are able to cause epigenetic alterations in cell-culture assays and in vivo animal studies. Some of the epigenetic modifications reported include decrease of global DNA methylation and altered methylation pattern of tumor suppressor genes in peripheral blood mononuclear cells (158, 159), differential methylated DNA regions in rat sperm (38), changes in the methylation status of Er $\alpha$ promoters in rat mammary gland (107), and finally, differential expression of non-coding RNAs in mouse brain $(160,161)$. Importantly, these epigenetic changes have been involved in diverse pathological processes, such as cancer development $(162,163)$, reproductive disorders $(164,165)$, and neurodegenerative diseases (166).

\section{Adverse Effects on Health of Successive Generations}

Maternal exposure to environmental chemicals during the preor perinatal period is considered an extremely sensitive window of exposure, which might affect embryogenesis or organogenesis leading to multiple types of defects in the progeny $(167,168)$. The consequences are evidenced by morphological, functional or biochemical alterations which in turn, lead to stillbirth, physical or cognitive disabilities or could predispose to certain pathologies at long-term (169-171). Evidences over the years have shown that these effects are not limited to the first generation (F1) but also may be transmitted to a second (F2) or even successive generations (172). An issue of particular concern regarding glyphosate and its formulations is the effect on offspring and subsequent generations in both animals and humans. In this section, we will address the effects on health of successive generations after maternal exposure to glyphosate or GBHs, even though paternal exposure is also an important factor. Table 4 summarizes the effects reported in F1 and F2 offspring in animal models after glyphosate or $\mathrm{GBH}$ exposure and the experimental conditions of the studies discussed in the present section.

Adverse reproductive effects of glyphosate and its formulations have been explored on offspring. Some of these effects include for example altered characteristics of the fetuses or newborn offspring such as weight, length, placental index, congenital anomalies as well as, neurodevelopmental changes detected in young offspring, among others which were determined not only in F1 but also F2 offspring. Particularly, our research group have evaluated the effect of perinatal exposure to a GBH (in a dose of 2 and $200 \mathrm{mg} / \mathrm{kg} /$ day) and glyphosate (alone) (in a dose of $2 \mathrm{mg} / \mathrm{kg} \mathrm{bw} / \mathrm{day}$ ) administered orally through food in Wistar rats from GD9 until birth and during the whole lactation period (as described above). When analyzing F1 offspring morphometric features such as weight, firstly we did not detect adverse effects in female at birth or weaning neither in Gly- nor GBH-treated group (31, 121). These results were supported by other authors' observations comparing the effects of glyphosate and a GBH after gestational (from GD6 onwards) plus lactational exposure in Sprague Dawley rats using $1.75 \mathrm{mg}$ of glyphosate $/ \mathrm{kg} /$ day through drinking water (173). Secondly, an interesting result we obtained was a lower litter birth weight in Gly-exposed group in comparison to control at the expense of a decrease in male weight which deserve further study. Meanwhile, outbred mouse pups prenatally exposed to glyphosate or a $\mathrm{GBH}$ whose mother received a solution of $0.5 \%$ of the active ingredient in the drinking water during the 21 days of pregnancy showed a decreased body weight at weaning (174). Authors exposed that this effect could be explained by previous results obtained using the same experimental model where they detected a decrease in the body weight of mothers during pregnancy (36). They hypothesized that it was as a result of energy consumption derived to detoxification instead of promoting offspring growth. Other study performed in Sprague Dawley rats by Kubsad et al. (38), also found lower weight in F1 offspring at weaning after glyphosate exposure. In this work, glyphosate was administered by daily intraperitoneal (ip) injections from GD8 until GD14 in a dose of $25 \mathrm{mg} / \mathrm{kg} /$ day. The discrepancy in the results between these works could be due to the different experimental conditions used (doses, mode of administration, animal model or time of exposure).

The occurrence of adverse effects in the second-generation of pups after $\mathrm{GBH}$ exposure was first reported by our research group $(121,122)$. F2 fetuses whose mothers had been exposed in utero and during lactation to a GBH formulation (2 or $200 \mathrm{mg}$ of glyphosate/kg bw/day) exhibited altered morphometric parameters on GD19. The higher dose induced a decrease in the body weight and length, while the lower dose caused a decrease in the fetal weight and a trend to lower fetal length; which indicates that the GBH formulation affected fetal growth. In a multigenerational animal model, gestational overexposure to dexamethasone caused similar effects on weight of F2 fetuses 
TABLE 4 | Effects of glyphosate (active ingredient) (Gly) and glyphosate-based herbicides (GBHs) associated with female fertility and those reported in the successive generations (F1, F2 or F3) of mammalian offspring after maternal exposure.

\begin{tabular}{|c|c|c|c|c|}
\hline Compound tested & Exposure type & Fertility associated effects & F1, F2 or F3 offspring effects & Reference \\
\hline -GBH: Roundup Full II & $\begin{array}{l}\text { Model: pregnant female rat } \\
\text { Exposure: subcutaneous } \\
\text { injections from postnatal day } \\
\text { (PND)1 to PND7 } \\
\text { Dose: } 2 \text { mg Gly/kg bw/day } \\
\text { Target of study: uterus }\end{array}$ & $\begin{array}{l}\text { GD9: } \\
\text {-altered endometrial decidualization process } \\
\text {-increased proliferation (Ki67) } \\
\text { GD19: } \\
\text {-increased rate of postimplantation losses }\end{array}$ & NR & (34) \\
\hline -GBH: Magnum Super II & $\begin{array}{l}\text { Model: pregnant female rat } \\
\text { Exposure: through food from } \\
\text { GD9 to LD21. } \\
\text { Dose: } 350 \mathrm{mg} \text { Gly/kg bw/day } \\
\text { Target of study: uterus }\end{array}$ & $\begin{array}{l}\text { F1 female rats } \\
\text { GD5: } \\
\text {-increased ER } \alpha \text { mRNA expression by increasing } \\
\text { ER } \alpha \text {-O transcript variant } \\
\text {-Epigenetic alterations in the O promoter of ER } \alpha\end{array}$ & NR & (37) \\
\hline -GBH: Magnum Super II & $\begin{array}{l}\text { Model: pregnant female rat (F0) } \\
\text { Exposure: through food from } \\
\text { GD9 to LD21. } \\
\text { Dose: } 2 \text { and } 200 \text { mg Gly/kg } \\
\text { bw/day } \\
\text { Target of study: uterus, } \\
\text { placenta, fetal parameters }\end{array}$ & $\begin{array}{l}\text { F1 female rats } \\
\text { GD19: } \\
200 \mathrm{mg} \text { Gly/kg bw/day } \\
\text {-increased rate of preimplantation losses }\end{array}$ & $\begin{array}{l}\text { F2 offspring } \\
\text { GD19: } \\
\mathbf{2 0 0 ~} \mathbf{~ m g ~ G l y / k g ~ b w / d a y : ~} \\
\text {-decreased fetal weight and length } \\
\text {-increased placental index } \\
\text {-structural congenital anomalies } \\
\mathbf{2} \mathbf{~ m g ~ G l y / k g ~ b w / d a y : ~} \\
\text {-decreased fetal weight }\end{array}$ & $(121,122)$ \\
\hline
\end{tabular}


TABLE 4 | Continued

\begin{tabular}{|c|c|c|c|c|}
\hline Compound tested & Exposure type & Fertility associated effects & F1, F2 or F3 offspring effects & Reference \\
\hline -GBH: Roundup & $\begin{array}{l}\text { Model: pregnant female rat } \\
\text { Exposure: by gavage from } \\
\text { GD6 to GD15 } \\
\text { Dose: } 500,750 \text { and } 1000 \mathrm{mg} \\
\text { Gly/kg bw/day } \\
\text { Target of study: multiple } \\
\text { organs }\end{array}$ & -no changes associated with female fertility & $\begin{array}{l}\text { All doses: } \\
\text {-increased occurrence of delayed } \\
\text { ossification in several body structures in } \\
\text { F1 fetuses }\end{array}$ & $(123)$ \\
\hline $\begin{array}{l}\text {-GBH: Roundup Full II } \\
\text {-Mixture (MIX): } \\
\text { commercial formulations } \\
\text { of Gly + endosulfan } \\
\text { (Endo) }\end{array}$ & $\begin{array}{l}\text { Model: neonatal and pregnant } \\
\text { female rat } \\
\text { Exposure: subcutaneous } \\
\text { injections from PND1 to PND7 } \\
\text { Dose: } 2 \mathrm{mg} \mathrm{Gly/kg} \mathrm{bw/day} \mathrm{or} 2 \\
\mathrm{mg} \text { Gly/kg bw/day + } 600 \mu \mathrm{gg} \\
\text { Endo/kg bw/day } \\
\text { Target of study: uterus }\end{array}$ & $\begin{array}{l}\text { PND8: } \\
\text { GBH and MIX: } \\
\text {-increased incidence of luminal epithelial } \\
\text { hyperplasia } \\
\text {-increased PR and Hoxa10 protein expression } \\
\text { GD19: } \\
\text { GBH and MIX: } \\
\text {-increased rate of postimplantation losses. }\end{array}$ & $N R$ & $(127)$ \\
\hline $\begin{array}{l}\text {-GBH: Roundup } \\
\text {-Mixture (MIX): } \\
\text { commercial formulations } \\
\text { of Gly + Paraquat }(\mathrm{Pq})\end{array}$ & $\begin{array}{l}\text { Model: pregnant female rat } \\
\text { Exposure: subcutaneous } \\
\text { injections from GD1 to GD7 } \\
\text { Dose: } 500 \mathrm{mg} \text { Gly/kg bw/day } \\
\text { or } 500 \mathrm{mg} \mathrm{Gly/kg} \mathrm{bw/day} \mathrm{+} 50 \\
\mathrm{mg} \mathrm{Pq} / \mathrm{kg} \text { bw/day } \\
\text { Target of study: uterus, ovary } \\
\text { and embryonic cells }\end{array}$ & $\begin{array}{l}\text { GD7: } \\
\text { GBH and MIX: } \\
\text {-decreased body and ovary weight } \\
\text {-decreased number of corpora lutea } \\
\text {-increased rate of preimplantation losses } \\
\text {-decreased surface and glandular epithelia and } \\
\text { diameter of endometrial glands } \\
\text { MIX: } \\
\text {-disorganization of the cytotrophoblast and cell } \\
\text { degeneration within the blastocyte cavity }\end{array}$ & $N R$ & $(128)$ \\
\hline -GBH: Kalach 360 SL & $\begin{array}{l}\text { Model: adult female rat } \\
\text { Exposure: trough water during } \\
60 \text { days } \\
\text { Dose: } 126 \text { and } 315 \mathrm{mg} \text { Gly/kg } \\
\text { bw/day } \\
\text { Target of study: ovary }\end{array}$ & $\begin{array}{l}\text { At the end of the treatment: } \\
\text {-impaired folliculogenesis and ovary } \\
\text { development. } \\
\text {-necrosis, vacuolisation of follicles, dissociated } \\
\text { oocytes and granulosa cells. } \\
\text {-increased atretic follicles. } \\
\text {-decreased E2 serum levels } \\
\text {-decreased antioxidant enzyme activities: } \\
\text { catalase (CAT), superoxide dismutase and } \\
\text { glutathione peroxidase (GP). }\end{array}$ & NR & $(129)$ \\
\hline $\begin{array}{l}\text {-GBH: Roundup Bioflow } \\
\text {-Gly }\end{array}$ & $\begin{array}{l}\text { Model: pregnant female rat } \\
\text { Exposure: through drinking } \\
\text { water from GD6 to } 6 \text {-weeks or } \\
13 \text { weeks after weaning } \\
\text { Dose: } 1.75 \mathrm{mg} \text { Gly/kg bw/day } \\
\text { Target of study: multiple } \\
\text { targets }\end{array}$ & $N R$ & $\begin{array}{l}\text { F1 offspring } \\
\text { Gly and GBH: } \\
\text {-altered developmental parameters } \\
\text { (anogenital distance, age at first estrous) } \\
\text {-altered sexual hormone concentrations } \\
\text {-specific sex-related and treatment- } \\
\text { related differences }\end{array}$ & $(173)$ \\
\hline $\begin{array}{l}\text {-GBH: Roundup } \\
\text {-Gly }\end{array}$ & $\begin{array}{l}\text { Model: pregnant female mouse } \\
\text { Exposure: trough drinking } \\
\text { water from GD1 to GD21 } \\
\text { Dose: } 5 \mathrm{mg} \mathrm{Gly/ml} \\
\text { Target of study: liver }\end{array}$ & $N R$ & $\begin{array}{l}\text { F1 offspring } \\
\text { Gly and GBH: } \\
\text {-decreased body weight at weaning } \\
\text {-disruption of lipid metabolism }\end{array}$ & $(174)$ \\
\hline -GBH: Glifloglex & $\begin{array}{l}\text { Model: pregnant female rat } \\
\text { Exposure: trough drinking } \\
\text { water from GD1 to LD21 } \\
\text { Dose: } 100 \text { and } 200 \mathrm{mg} \text { Gly/kg } \\
\text { bw/day } \\
\text { Target of study: brain }\end{array}$ & $N R$ & $\begin{array}{l}\text { F1 offspring } \\
\text {-early onset of cliff aversion reflex and } \\
\text { auditory canal opening. } \\
\text {-decreased locomotor activity and anxiety } \\
\text { levels } \\
\text {-exacerbated emotionality }\end{array}$ & $(175)$ \\
\hline -GBH: Glifloglex & $\begin{array}{l}\text { Model: pregnant female rat } \\
\text { Exposure: trough drinking } \\
\text { water from GD1 to LD21 } \\
\text { Dose: } 100 \text { and } 200 \mathrm{mg} \text { Gly/kg } \\
\text { bw/day } \\
\text { Target of study: brain }\end{array}$ & $N R$ & $\begin{array}{l}\text { F1 offspring } \\
\text {-altered antioxidant status } \\
\text {-altered enzymes activity involved in } \\
\text { glutamatergic and cholinergic systems } \\
\text {-impairment in recognition memory }\end{array}$ & $(176)$ \\
\hline
\end{tabular}


TABLE 4 | Continued

\begin{tabular}{|c|c|c|c|c|}
\hline Compound tested & Exposure type & Fertility associated effects & F1, F2 or F3 offspring effects & Reference \\
\hline -GBH: Roundup & $\begin{array}{l}\text { Model: pregnant female rat } \\
\text { Exposure: trough oral gavage } \\
\text { from GD0 to LD21 } \\
\text { Dose: } 250 \text { and } 500 \mathrm{mg} \text { Gly/kg } \\
\text { bw/day } \\
\text { Target of study: brain }\end{array}$ & -decreased fertility rate and gestational index & $\begin{array}{l}\text { F1 offspring } \\
\text {-decreased number of pups per litter } \\
\text {-decreased body weight on PND15 and } \\
\text { PND21 } \\
\text { Offspring: delayed reflexes and altered } \\
\text { motor development } \\
\text { Adults: decreased locomotor activity, } \\
\text { sociability, learning and impaired memory }\end{array}$ & (177) \\
\hline -Gly & $\begin{array}{l}\text { Model: pregnant female rat } \\
\text { Exposure: ip injections every } \\
48 \text { hs from GD } 8 \text { to GD20 } \\
\text { Dose: } 24 \text { and } 35 \text { mg Gly/kg } \\
\text { bw/day } \\
\text { Target of study: brain }\end{array}$ & $N R$ & $\begin{array}{l}\text { F1 offspring } \\
\text {-decreased body weight in pups from } \\
\text { PND19 } \\
\text {-altered dose-dependent reflexes } \\
\text { development, motor activity and cognitive } \\
\text { function } \\
\text {-altered Wnt5a-CaMKII pathway in fetal } \\
\text { hippocampus }\end{array}$ & $(178)$ \\
\hline $\begin{array}{l}\text {-GBH: Roundup } \\
\text { Transorb }\end{array}$ & $\begin{array}{l}\text { Model: pregnant female rat } \\
\text { Exposure: by oral gavage from } \\
\text { GD18 to LD5 } \\
\text { Dose: } 5 \text { and } 50 \mathrm{mg} \text { Gly/kg } \\
\text { bw/day } \\
\text { Target of study: brain } \\
\text { (cerebellum and cortex) }\end{array}$ & NR & $\begin{array}{l}\text { F1 male offspring (PND90) } \\
\text {-altered gene expression involved in } \\
\text { oxidant defense, inflammation and lipid } \\
\text { metabolism } \\
\text {-correlation of changes in gene } \\
\text { expression with serum concentrations of } \\
\text { oxidative stress-related metabolites }\end{array}$ & $(179)$ \\
\hline -GBH: Roundup Maxload & $\begin{array}{l}\text { Model: pregnant female mouse } \\
\text { Exposure: trough drinking } \\
\text { water from GD5 to LD21 } \\
\text { Dose: } 12.5 \text { mg Gly/kg bw/day } \\
\text { Target of study: brain } \\
\text { (prefrontal cortex, hippocampus } \\
\text { and striatum) }\end{array}$ & NR & $\begin{array}{l}\text { F1 juvenile offspring (PND28-PND35) } \\
\text {-autism spectrum disorder (ASD)-like } \\
\text { behavioral abnormalities (cognitive and } \\
\text { social interaction deficits) } \\
\text {-increased soluble epoxide hydrolase } \\
\text { (sEH) expression } \\
\text {-ASD-like behaviors prevented by oral } \\
\text { administration of an sEH inhibitor } \\
\text {-abnormal composition of gut microbiota }\end{array}$ & $(180)$ \\
\hline
\end{tabular}

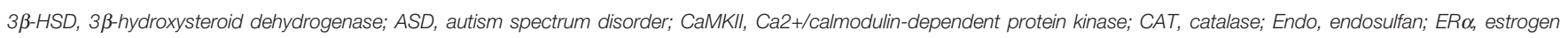
receptor alpha; GBH, glyphosate based-herbicide; GD, gestational day; Gly, glyphosate (active ingredient); GP, glutathione peroxidase; Hoxa10, Homeobox A10; ip, intraperitoneal; LD, lactational day; Lif, Leukemia inhibitory factor; LHR, luteinizing hormone receptor; MIX, mixture; NR, Not reported; PND, postnatal day; PR, progesterone receptor; Pq, paraquat; sEH, soluble epoxide hydrolase; Wnt5a, wingless-type MMTV integration site.

(181). It is known that fetal growth is a predictor of child health because its impairment may be associated with poor neurodevelopment (182) and chronic diseases later in life such as obesity, insulin resistance and type 2 diabetes, coronary heart disease, hypertension, among others (183-185). Epidemiological reports on fetal growth are scarce given that most studies used birth weight as a proxy measure of intrauterine growth (186). Importantly, several epidemiological studies have found a significant association between environmental or occupational maternal exposure to pesticides and decreased birth weight and length (187-190).

In addition to the effect on fetal parameters, placental index which is defined as the ratio of placental weight to fetal body weight was found to be high in F2 offspring from dams exposed to GBH in a dose of $200 \mathrm{mg}$ of glyphosate/kg bw/day. Our results indicated that the higher placental index was at expense of a decrease in fetal weight (122). The placental index reflects the balance between fetal and placental growth. In normal conditions, placental index decreases across gestation as the placenta matures and the fetal weight increases (191). It allows to estimate how placental development adapts to reach fetal nutritional requirements (192). It has been suggested that adaptations take place in order to maintain appropriate fetal growth, and a failure in this process may result in a fetus that is either small or large with respect to its genetic growth potential (193). According to Macdonald et al. (194), obstetric outcomes, particularly indicators of fetal hypoxia and placental dysfunction, were associated with elevated placental index, which might explain our experiment results. Moreover, placental index may evidence maternal diseases and predict pregnancy outcomes, perinatal morbidity and mortality, and child growth and development $(191,195,196)$. In this regard, a retrospective study of 18,386 pregnancies found a high placental index associated with pregnancies characterized by poor outcomes, such as hypertensive disorders, impaired fetal growth and complicated post-natal infant care (197). So far, the mechanisms leading to the alterations of these feto-placental parameters induced by perinatal exposure to $\mathrm{GBH}$ remains to be elucidated.

Structural congenital anomalies are other adverse pregnancy outcomes we detected in F2 offspring from mothers perinatally exposed to a GBH formulation in a dose of $200 \mathrm{mg}$ of glyphosate/ $\mathrm{kg}$ bw/day. These anomalies involved conjoined fetuses and 
abnormally developed limbs (i.e., fetuses lacking one of their extremities or displaying longitudinal reduction of the tail) (121, 122). The finding of congenital anomalies in F2 offspring is of remarkable importance since this kind of effects result from F1 fetal germ cells (represented by F2 generation) modification, and open the possibility to transmit these alterations to the subsequent generations through genetic or epigenetic mechanisms (198). It is worthy to mention that teratogenic potential of both glyphosate and GBHs has been shown in different species of vertebrates (zebrafish, amphibian, chicken and rat) after developmental exposure, and when testing doses of environmental relevance or below regulatory limits (for maternal and fetal toxicity) $(123,199-$ 201). For example, a study carried out in Wistar rats observed significantly higher occurrence of delayed ossification in several body structures in $\mathrm{F} 1$ fetuses whose mothers were treated with a $\mathrm{GBH}$ formulation. At the lowest dose evaluated $(500 \mathrm{mg}$ of glyphosate $/ \mathrm{kg} /$ day) which corresponds to the half of no observed adverse effect level (NOAEL) for maternal and developmental toxicity in rats (202), 33.1\% of the fetuses exhibited skeletal alterations, denoting detrimental effects at doses considered to be safe. In Figure 1, we summarize the multigenerational effects we detected after perinatal exposure (during gestation and lactation) to a glyphosate-based herbicide and the active ingredient on F1 female rats at adulthood and their F2 offspring.

Regarding the effects on nervous system functions, agrochemical exposure has been proposed as a risk factor for human neurodegenerative disorders (203-205) and glyphosate and GBHs are not the exception. In this sense, two case reports of acute and chronic exposure to GBHs have been associated with parkinsonism, a condition similar to Parkinson's disease (206, 207). In addition to that, a population-based case-control study in USA showed that autism spectrum disorder (ASD), a developmental disorder, was associated with prenatal exposure to glyphosate (during pregnancy) with odds ratio (OR): 1.16 (CI 1.06 to 1.27 ) raising by about $30 \%$ for ASD with intellectual disability (208). For cases with ASD with intellectual disability, when coadjusting for developmental period-specific exposures such as, the first year of life, the associations became strongest (OR: 1.60; CI 1.09 to 2.34). Moreover, neurotoxic effects of this herbicide have been extensively documented in experimental studies (209-211). We focused our attention on those studies reporting brain alterations in offspring from dams treated with the herbicide. For instance, Gallegos et al. $(175,176)$, assessed the neurobehavioral effects of a $\mathrm{GBH}$ formulation supplied to Wistar rats during the whole gestation and lactation period through drinking water. Researchers evaluated two doses of glyphosate of 100 and $200 \mathrm{mg} / \mathrm{kg} /$ day and offspring were subjected to a series of tests on postnatal day 45 and 90 . They found a decrease in locomotor activity and anxiety, exacerbated emotionality (175) and impairment in recognition memory (176) in the exposed offspring. Later, other works evaluating a similar exposure window (gestation or/and lactation period) found that either a GBH formulation or Gly (active ingredient) induces numerous behavioral and cognitive alterations in pups and adult offspring, which is in line with previous findings $(177,178)$ (further details in Table 4). Also, the study of de Souza et al. (179), indicated that maternal GBH exposure in doses of 5 and $50 \mathrm{mg}$ of glyphosate/ $\mathrm{kg} /$ day could have lasting effects on brain functions of rat offspring. Authors reported altered expression of molecules participating in the oxidative and inflammatory response in the cerebellum and cortex of 90-day-old male rat offspring. Additionally, gene expression deregulation induced by $\mathrm{GBH}$ was correlated with changes in the serum concentrations of some oxidative stressrelated metabolites such as, lysophosphatidylcholine and phosphatidylcholine which were associated with neurodegenerative diseases. These alterations might contribute to neural damage increasing the risk of developing neurological pathologies. Recently, a work detected ASD-like behavioral abnormalities in juvenile mouse offspring after maternal exposure to a GBH formulation. The herbicide formulation was provided to pregnant mice from GD5 until weaning in a dose of $12.5 \mathrm{mg} / \mathrm{kg} /$ day through drinking water. An increased protein expression of soluble epoxide hydrolase $(\mathrm{sEH})$ was reported in the prefrontal cortex, hippocampus and striatum from juvenile $\mathrm{GBH}$-exposed offspring. Interestingly, when a sEH inhibitor was supplemented during the treatment, the behavioral disturbances were prevented. So, authors proposed $\mathrm{sEH}$ as a factor implicated in the development of this behavior disorder (180). Also, in this work, abnormal composition of gut microbiota was detected in GBH-exposed offspring. As recent research pointed an interaction between altered microbiota and ASD (212), more studies are needed in order to explore the role of gut microbiota on glyphosate-induced ASD. To our knowledge, glyphosate- or GBHinduced brain-related disturbances have not been reported beyond the first generation of offspring. According to the current data, preand early postnatal exposure to glyphosate or GBH might lead to impairment of the cognitive performance and behavioral functions of offspring.

Finally, Kubsad and colleagues (38) determined that glyphosate in a dose of $25 \mathrm{mg} / \mathrm{kg}$ bw/day is able to induce transgenerational effects. They investigated a transient glyphosate exposure on gestating F0 outbred Sprague Dawley rats which were treated with daily ip injections from GD8 until GD14. Researchers evaluated the frequency of several pathologies in different generations: F0 adult females directly exposed to glyphosate, F1 and F2 offspring directly exposed in their condition as fetus and fetus' germline respectively, and F3 offspring, the first unexposed generation to the herbicide. Alarming results indicated minor effects on F0 and F1 generations, and higher incidence of histological abnormalities in different organs (prostate, testis, kidney and ovary) and pathologies such as obesity, parturition complications and tumor development (specifically mammary adenomas) in F2 and F3 one-year old rats. Also, differential DNA methylation regions (DMRs) were identified in sperm from control and Gly-treated animals in F1, F2 and F3 generations. The most frequent DMR associated gene categories were transcription, signaling, metabolism, receptors, and cytoskeleton which are mainly involved in metabolic, signaling, cancer and endocytosis pathways (38). Although the functional role of altered DNA methylation along the generations remains to be elucidated, authors proposed that the pathologies observed in the F3 generation emerge in part, as the result of epigenetic alterations or "epimutations". This particular phenomenon, in 


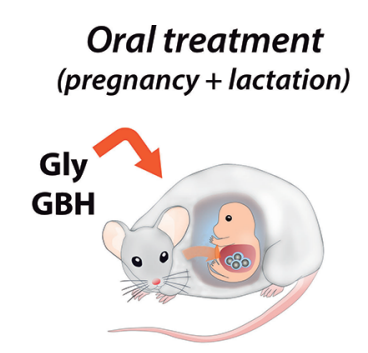

F0 Dams
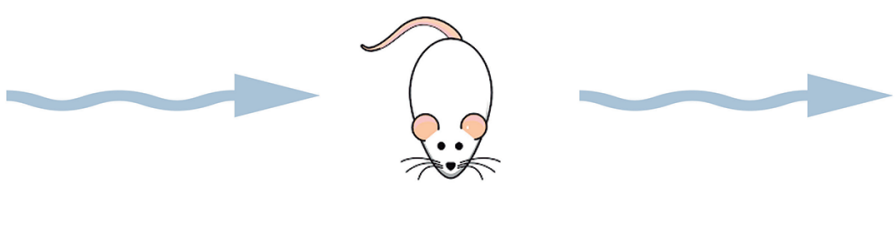

F1 Dams<smiles>C1C2CC1C2</smiles>

Preimplantation

embryo losses

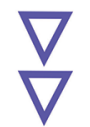

Hormonal and uterine mechanisms of action

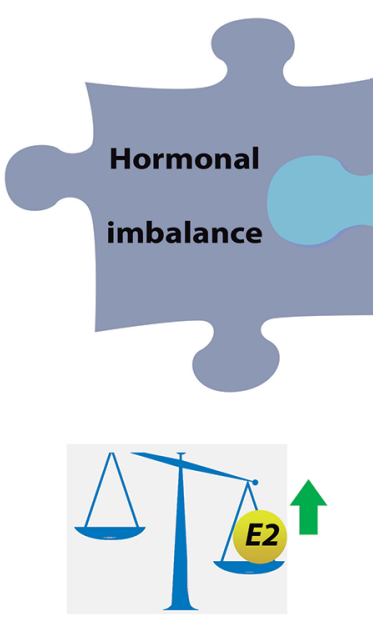

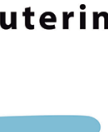

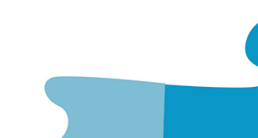

Disruption of implantationrelated molecules

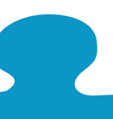

.
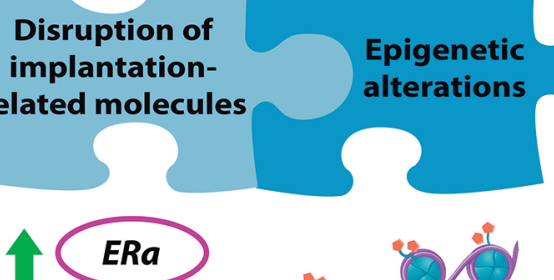

ERa

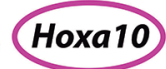

Lif

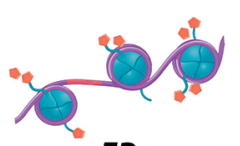

ERa gene:

-DNA hypomethylation

-Altered histone posttranslational modifications
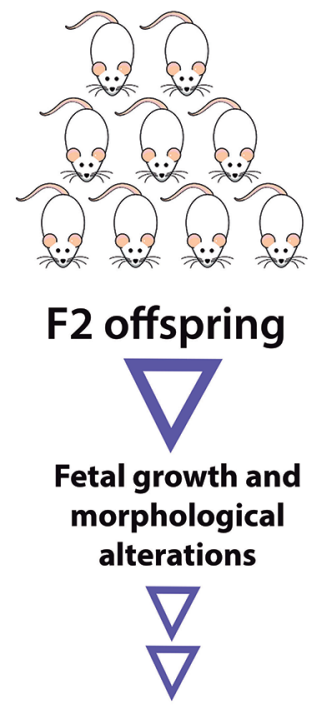

Fetal Length

Fetal body weight

Placental index

Structural anomalies

FIGURE 1 | The scheme summarizes the multigenerational effects of the herbicide glyphosate (active ingredient and a glyphosate-based herbicide) on F1 adult female rats and their F2 offspring after perinatal exposure (during gestation and lactation) through food. The color green or red of the arrows denotes induction or inhibition of the molecular targets, respectively. Gly, glyphosate (active ingredient); GBH, glyphosate-based herbicide; E2, 17ß-estradiol; ER $\alpha$, estrogen receptor alpha; Lif, Leukemia inhibitory factor; Hoxa10, Homeobox A10.

which F3 animals that never had contact with the chemical exhibit higher number of alterations than the previous generations, was also reported for the herbicide atrazine (213). To sum up, all the evidence presented in this section highlights the importance and need of further evaluating the toxicology of glyphosate and its formulations through the successive generations.

\section{LIMITATIONS OF ANIMAL STUDIES FOR PREDICTING HUMAN EXPOSURE TO GBHS}

A concern question about using laboratory animals as models to predict human health risk, is whether they are truly representative of actual human or environmental exposure. As stated Hartung (214) in his revision, no model is perfect, and the term "model" implies deviation from reality. Despite that, animal models are fundamental tools in the life sciences, and conclusions should be interpreted with caution when predicting chemical hazards or health risk. In the particular case of glyphosate, major limitations in some studies keep animals models away from representative chronic human exposure, such as, unrealistic high-dose treatment and short exposure duration, administration routes which not represent that of human exposure like subcutaneous or ip injections, toxicological assessment based on the effects of pure glyphosate instead of GBHs which can underestimate toxicity. However, in the last few years several studies have been conducted applying more complex experimental designs in an attempt to better reflect human and 
environmental exposure, i.e., oral exposure to the herbicide through adding it into drinking water or food, longer exposure periods (for example, during gestation and lactation), assessment of doses representative of glyphosate residues from sprayed crops (plants or seeds), or doses that are in the order of magnitude of the levels detected in different environmental matrixes, or that reflect the RfD established by regulatory agencies. However, no study replicates actual modes of ingestion, and experimental works providing animals with food contaminated with glyphosate at the levels found in food stuff or drinking water/groundwater should be performed not only in the common laboratory animal models but also, in farm animals for human consumption. To determine the actual risk of glyphosate and to help set safe exposure limits, studies are needed to determine how much glyphosate from food is taken to the body. In addition, to bridge between animal models and human exposure, dietary or environmental (air) exposure needs to be correlated with levels of glyphosate and AMPA in the body.

Another matter to be considered is the lack of studies dealing with the consequences for health of the co-formulants classified as "inert" ingredients in herbicide formulations. As coformulants are treated as a trade secret by the manufacturers, the composition of practically most of the GBHs are unknown. Moreover, as the composition of co-formulants and their relative concentrations may differ among GBH brands, it is difficult to evaluate their contribution to the herbicide toxicity (215).

\section{CONCLUDING REMARKS AND FUTURE DIRECTIONS}

As Argentina is one of the countries with the highest consumption of glyphosate-tolerant seeds and glyphosate formulations, we know from very close experience the tight dependence of the economy on extensive agriculture and GBHs. As long as new biotechnological events which confer tolerance to glyphosate got approval, the usage of $\mathrm{GBH}$ formulations will continue rising.
This, in addition to the fact that the yield of genetically modified crops is highly superior than those crops not modified, motivates farmers to choose the technological package of genetically modified seeds and glyphosate herbicide. Also, despite the spread of weed resistance to glyphosate, there are few initiatives to analyze strategies for farming with limited or without glyphosate use. Some alternative methodologies include precision agricultural systems, mechanical weed control systems, bioherbicides, among others $(216,217)$. Unfortunately, currently available herbicides, which might be proposed as alternatives to glyphosate, are very limited, less effective, and more expensive, or even may have a worse ecotoxicological profile than glyphosate (218). So, in this scenario, our role as scientists is to show the evidence to the scientific community but also, to make know what is reported in the literature to the general community. Through this way, we will be able to dialogue, educate and raise awareness on the risks of excessive use of these pesticides mainly of those who manipulate the herbicide formulations or are responsible directly or indirectly of their use. Also, it is important that people take into account potential acute effects, but also long-term effects and possible impact on the health of subsequent generations; emphasizing on the health care of women preconceptionally and during pregnancy (especially those who could be occupationally exposed to higher levels than general population). Although there is extensive accumulated experimental evidence about the negative impact of glyphosate and GBHs on pregnancy outcomes, there are just a few epidemiological studies on reproductive health to arrive to conclusive definitions. Therefore, it is urged that more assessments will be a priority at this stage and we are focusing our efforts on this issue.

\section{AUTHOR CONTRIBUTIONS}

All authors contributed to the manuscript design, writing, and editing. MM, MD, and JV are Career Investigators of the CONICET. VL and MR are fellows of CONICET. All authors contributed to the article and approved the submitted version.

\section{REFERENCES}

1. Benbrook CM. Trends in Glyphosate Herbicide Use in the United States and Globally. Environ Sci Eur (2016) 28:3. doi: 10.1186/s12302-016-0070-0

2. Duke SO. The History and Current Status of Glyphosate. Pest Manag Sci (2018) 74:1027-34. doi: 10.1002/ps.4652

3. Cuhra M, Bøhn T, Cuhra P. Glyphosate: Too Much of a Good Thing? Front Environ Sci (2016) 4:28. doi: 10.3389/fenvs.2016.00028

4. ISAAA. Global Status of Commercialized Biotech/GM Crops in 2018: Biotech Crops Continue to Help Meet the Challenges of Increased Population and Climate Change. Brief No. 54, ISAAA, US (2018). Available at: https://www. isaaa.org/resources/publications/briefs/54/download/isaaa-brief-54-2018.pdf (Accessed January 25, 2021).

5. Kleffmanngroup. Informe Del Mercado Argentino De Productos Fitosanitarios (2012). Available at: http://www.casafe.org/publicaciones/estadisticas/ (Accessed January 25, 2021).

6. Duke SO, Powles SB. Glyphosate: A Once-in-a-Century Herbicide. Pest Manag Sci (2008) 64:319-25. doi: 10.1002/ps.1518

7. Paris P, Pace E, Parisi Presicce D, Maschio G, Ursino S. Rapporto Nazionale Pesticidi Nelle Acque. Dati 2013-2014, Rapporti 244/2016. Italia: ISPRA (2016).

8. Singh S, Kumar V, Gill JPK, Datta S, Singh S, Dhaka V, et al. Herbicide Glyphosate: Toxicity and Microbial Degradation. Int J Environ Res Public Health (2020) 17:7519. doi: 10.3390/ijerph17207519

9. Knaggs AR. The Biosynthesis of Shikimate Metabolites. Nat Prod Rep (2001) 18:334-55. doi: 10.1039/b001717p

10. Lozano VL, Defarge N, Rocque LM, Mesnage R, Hennequin D, Cassier R, et al. Sex-Dependent Impact of Roundup on the Rat Gut Microbiome. Toxicol Rep (2018) 5:96-107. doi: 10.1016/j.toxrep.2017.12.005

11. Mao Q, Manservisi F, Panzacchi S, Mandrioli D, Menghetti I, Vornoli A, et al. The Ramazzini Institute 13-Week Pilot Study on Glyphosate and Roundup Administered at Human-Equivalent Dose to Sprague Dawley Rats: Effects on the Microbiome. Environ Health (2018) 17:50. doi: 10.1186/s12940-018-0394-x

12. Nielsen LN, Roager HM, Casas ME, Frandsen HL, Gosewinkel U, Bester K, et al. Glyphosate has Limited Short-Term Effects on Commensal Bacterial Community Composition in the Gut Environment Due to Sufficient Aromatic Amino Acid Levels. Environ Pollut (2018) 233:364-76. doi: 10.1016/ j.envpol.2017.10.016

13. Riede S, Toboldt A, Breves G, Metzner M, Köhler B, Bräunig J, et al. Investigations on the Possible Impact of a Glyphosate-Containing Herbicide on Ruminal Metabolism and Bacteria In Vitro by Means of the 'Rumen 
Simulation Technique'. J Appl Microbiol (2016) 121:644-56. doi: 10.1111/ jam. 13190

14. Krause JL, Haange SB, Schäpe SS, Engelmann B, Rolle-Kampczyk U, FritzWallace K, et al. The Glyphosate Formulation Roundup ${ }^{\circledR}$ LB Plus Influences the Global Metabolome of Pig Gut Microbiota In Vitro. Sci Total Environ (2020) 745:140932. doi: 10.1016/j.scitotenv.2020.140932

15. Mesnage R, Teixeira M, Mandrioli D, Falcioni L, Ducarmon QR, Zwittink RD, et al. Use of Shotgun Metagenomics and Metabolomics to Evaluate the Impact of Glyphosate or Roundup MON 52276 on the Gut Microbiota and Serum Metabolome of Sprague Dawley Rats. Environ Health Perspect (2021) 129:17005. doi: 10.1289/EHP6990

16. Bai SH, Ogbourne SM. Glyphosate: Environmental Contamination, Toxicity and Potential Risks to Human Health Via Food Contamination. Environ Sci Pollut Res Int (2016) 23:18988-9001. doi: 10.1007/s11356-016-7425-3

17. Heap I, Duke SO. Overview of Glyphosate-Resistant Weeds Worldwide. Pest Manag Sci (2018) 74:1040-9. doi: 10.1002/ps.4760

18. Bonny S. Genetically Modified Herbicide-Tolerant Crops, Weeds, and Herbicides: Overview and Impact. Environ Manage (2016) 57:31-48. doi: 10.1007/s00267-015-0589-7

19. Montiel-León JM, Munoz G, Vo Duy S, Do DT, Vaudreuil MA, Goeury K, et al. Widespread Occurrence and Spatial Distribution of Glyphosate, Atrazine, and Neonicotinoids Pesticides in the St. Lawrence and tributary rivers. Environ Pollut (2019) 250:29-39. doi: 10.1016/j.envpol.2019.03.125

20. Demonte LD, Michlig N, Gaggiotti M, Adam CG, Beldoménico HR, Repetti MR. Determination of Glyphosate, AMPA and Glufosinate in Dairy Farm Water From Argentina Using a Simplified UHPLC-MS/MS Method. Sci Total Environ (2018) 645:34-43. doi: 10.1016/j.scitotenv.2018.06.340

21. Lupi L, Bedmar F, Puricelli M, Marino D, Aparicio VC, Wunderlin D, et al. Glyphosate Runoff and Its Occurrence in Rainwater and Subsurface Soil in the Nearby Area of Agricultural Fields in Argentina. Chemosphere (2019) 225:906-14. doi: 10.1016/j.chemosphere.2019.03.090

22. Mendez MJ, Aimar SB, Aparicio VC, Ramirez Haberkon NB, Buschiazzo DE, De Gerónimo E, et al. Glyphosate and Aminomethylphosphonic Acid (AMPA) Contents in the Respirable Dust Emitted by an Agricultural Soil of the Central Semiarid Region of Argentina. Aeolian Res (2017) 29:23-9. doi: 10.1016/j.aeolia.2017.09.004

23. Ravier S, Désert M, Gille G, Armengaud A, Wortham H, Quivet E. Monitoring of Glyphosate, Glufosinate-Ammonium, and (Aminomethyl)Phosphonic Acid in Ambient Air of Provence-Alpes-Côte-D'Azur Region, France. Atmos Environ (2019) 204:102-9. doi: 10.1016/j.atmosenv.2019.02.023

24. Rendon-von Osten J, Dzul-Caamal R. Glyphosate Residues in Groundwater, Drinking Water and Urine of Subsistence Farmers From Intensive Agriculture Localities: A Survey in Hopelchén, Campeche, Mexico. Int J Environ Res Public Health (2017) 14:595. doi: 10.3390/ijerph14060595

25. Rodrigues NR, Ferreira de Souza AP. Occurrence of Glyphosate and AMPA Residues in Soy-Based Infant Formula Sold in Brazil. Food Addit Contam (2018) 35:723-30. doi: 10.1080/19440049.2017.1419286

26. Rubio F, Guo E, Kamp L. Survey of Glyphosate Residues in Honey, Corn and Soy Products. J Environ Anal Toxicol (2014) 4:249. doi: 10.4172/21610525.1000249

27. Mesnage R, Antoniou MN. Ignoring Adjuvant Toxicity Falsifies the Safety Profile of Commercial Pesticides. Front Public Health (2018) 5:361. doi: 10.3389/fpubh.2017.00361

28. Defarge N, Takács E, Lozano VL, Mesnage R, Spiroux de Vendômois J, Seralini GE, et al. Co-Formulants in Glyphosate-Based Herbicides Disrupt Aromatase Activity in Human Cells Below Toxic Levels. Int J Environ Res Public Health (2016) 13:264. doi: 10.3390/ijerph13030264

29. Johansson HKL, Schwartz CL, Nielsen LN, Boberg J, Vinggaard AM, Bahl MI, et al. Exposure to a Glyphosate-Based Herbicide Formulation, But Not Glyphosate Alone, Has Only Minor Effects on Adult Rat Testis. Reprod Toxicol (2018) 82:25-31. doi: 10.1016/j.reprotox.2018.09.008

30. Mesnage R, Defarge N, Spiroux de Vendômois J, Seralini GE. Major Pesticides Are More Toxic to Human Cells Than Their Declared Active Principles. BioMed Res Int (2014) 2014:179691. doi: 10.1155/2014/179691

31. Lorenz V, Pacini G, Luque EH, Varayoud J, Milesi MM. Perinatal Exposure to Glyphosate or a Glyphosate-Based Formulation Disrupts Hormonal and Uterine Milieu During the Receptive State in Rats. Food Chem Toxicol (2020) 143:111560. doi: 10.1016/j.fct.2020.111560
32. Pham TH, Derian L, Kervarrec C, Kernanec P-Y, Jégou B, Smagulova F, et al. Perinatal Exposure to Glyphosate and a Glyphosate-Based Herbicide Affect Spermatogenesis in Mice. Toxicol Sci (2019) 169:260-71. doi: 10.1093/toxsci/kfz039

33. Perego MC, Schutz LF, Caloni F, Cortinovis C, Albonico M, Spicer LJ. Evidence for Direct Effects of Glyphosate on Ovarian Function: Glyphosate Influences Steroidogenesis and Proliferation of Bovine Granulosa But Not Theca Cells In Vitro. J Appl Toxicol (2017) 37:692-8. doi: 10.1002/jat.3417

34. Ingaramo PI, Varayoud J, Milesi MM, Guerrero Schimpf M, Muñoz de Toro M, Luque EH. Effects of Neonatal Exposure to a Glyphosate-Based Herbicide on Female Rat Reproduction. Reproduction (2016) 152:403-15. doi: 10.1530/ REP-16-0171

35. Guerrero Schimpf M, Milesi MM, Ingaramo P, Luque E, Varayoud J. Neonatal Exposure to a Glyphosate-Based Herbicide Alters the Development of the Rat Uterus. Toxicology (2017) 376:2-14. doi: 10.1016/j.tox.2016.06.004

36. Ren X, Li R, Liu J, Huang K, Wu S, Li Y, et al. Effects of Glyphosate on the Ovarian Function of Pregnant Mice, the Secretion of Hormones and the Sex Ratio of Their Fetuses. Environ Pollut (2018) 243:833-41. doi: 10.1016/ j.envpol.2018.09.049

37. Lorenz V, Milesi MM, Guerrero Schimpf M, Luque EH, Varayoud J. Epigenetic Disruption of Estrogen Receptor Alpha Is Induced by a Glyphosate-Based Herbicide in the Preimplantation Uterus of Rats. Mol Cell Endocrinol (2019) 480:133-41. doi: 10.1016/j.mce.2018.10.022

38. Kubsad D, Nilsson EE, King SE, Sadler-Riggleman I, Beck D, Skinner MK. Assessment of Glyphosate Induced Epigenetic Transgenerational Inheritance of Pathologies and Sperm Epimutations: Generational Toxicology. Sci Rep (2019) 9:6372. doi: 10.1038/s41598-019-42860-0

39. Ben Maamar M, Beck D, Nilsson EE, Kubsad D, Skinner MK. EpigenomeWide Association Study for Glyphosate Induced Transgenerational Sperm DNA Methylation and Histone Retention Epigenetic Biomarkers for Disease. Epigenetics (2020) 1-18. doi: 10.1080/15592294.2020.1853319

40. Environmental Protection Agency (EPA). Chemical: Glyphosate. EDSP: Weight of Evidence Analysis of Potential Interaction With the Estrogen, Androgen or Thyroid Pathways. Washington DC, USA: Office of Pesticide Programs US EPA (2015). Available at: http://www.epa.gov/sites/production/ files/2015-06/documents/glyphosate-4173002015-06-29txr0057175.pdf.

41. European Food Safety Authority (EFSA). Peer Review of the Pesticide Risk Assessment of the Potential Endocrine Disrupting Properties of Glyphosate. EFSA J (2017) 15:e04979. doi: 10.2903/j.efsa.2017.4979

42. Llop S, Murcia M, Iñiguez C, Roca M, González L, Yusà V, et al. Distributions and Determinants of Urinary Biomarkers of Organophosphate Pesticide Exposure in a Prospective Spanish Birth Cohort Study. Environ Health (2017) 16:46. doi: 10.1186/s12940-017-0255-z

43. Lu C, Barr Dana B, Pearson Melanie A, Waller Lance A. Dietary Intake and its Contribution to Longitudinal Organophosphorus Pesticide Exposure in Urban/Suburban Children. Environ Health Perspect (2008) 116:537-42. doi: 10.1289/ehp.10912

44. van den Dries MA, Pronk A, Guxens M, Spaan S, Voortman T, Jaddoe VW, et al. Determinants of Organophosphate Pesticide Exposure in Pregnant Women: A Population-Based Cohort Study in the Netherland. Int J Hyg Environ Health (2018) 221:489-501. doi: 10.1016/j.ijheh.2018.01.013

45. Pollegioni L, Schonbrunn E, Siehl D. Molecular Basis of Glyphosate Resistance-Different Approaches Through Protein Engineering. FEBS $J$ (2011) 278:2753-66. doi: 10.1111/j.1742-4658.2011.08214.x

46. Arregui MC, Lenardón A, Sanchez D, Maitre MI, Scotta R, Enrique S. Monitoring Glyphosate Residues in Transgenic Glyphosate-Resistant Soybean. Pest Manag Sci (2004) 60:163-6. doi: 10.1002/ps.775

47. Testbiotech. High Levels of Residues From Spraying With Glyphosate Found in Soybeans in Argentina (2013). Available at: https://www.testbiotech.org/en/ content/high-levels-residues-spraying-glyphosate-found-soybeans-argentina (Accessed January 25, 2021).

48. Granby K, Johannesen S, Vahl M. Analysis of Glyphosate Residues in Cereals Using Liquid Chromatography-Mass Spectrometry (LC-MS/MS). Food Addit Contam (2003) 20:692-8. doi: 10.1080/0265203031000109477

49. Zoller O, Rhyn P, Rupp H, Zarn JA, Geiser C. Glyphosate Residues in Swiss Market Foods: Monitoring and Risk Evaluation. Food Addit Contam Part B Surveill (2018) 11:83-91. doi: 10.1080/19393210.2017.1419509

50. Bøhn T, Cuhra M, Traavik T, Sanden M, Fagan J, Primicerio R. Compositional Differences in Soybeans on the Market: Glyphosate 
Accumulates in Roundup Ready GM Soybeans. Food Chem (2014) 153:20715. doi: 10.1016/j.foodchem.2013.12.054

51. Ronco AE, Marino DJG, Abelando M, Almada P, Apartin CD. Water Quality of the Main Tributaries of the Paraná Basin: Glyphosate and AMPA in Surface Water and Bottom Sediments. Environ Monit Assess (2016) 188:458. doi: 10.1007/s10661-016-5467-0

52. Castro Berman M, Marino DJG, Quiroga MV, Zagarese H. Occurrence and Levels of Glyphosate and AMPA in Shallow Lakes From the Pampean and Patagonian Regions of Argentina. Chemosphere (2018) 200:513-22. doi: 10.1016/j.chemosphere.2018.02.103

53. Gunarathna S, Gunawardana B, Jayaweera M, Manatunge J, Zoysa K. Glyphosate and AMPA of Agricultural Soil, Surface Water, Groundwater and Sediments in Areas Prevalent With Chronic Kidney Disease of Unknown Etiology, Sri Lanka. J Environ Sci Health B (2018) 53:729-37. doi: 10.1080/ 03601234.2018 .1480157

54. Reynoso EC, Peña RD, Reyes D, Chavarin-Pineda Y, Palchetti I, Torres E. Determination of Glyphosate in Water From a Rural Locality in México and its Implications for the Population Based on Water Consumption and Use Habits. Int J Environ Res Public Health (2020) 17:7102. doi: 10.3390/ ijerph 17197102

55. European Food Safety Authority (EFSA). Conclusion on the Peer Review of the Pesticide Risk Assessment of the Active Substance Glyphosate. EFSA J (2015) 13:4302. doi: 10.2903/j.efsa.2015.4302

56. Agência Nacional de Vigilância Sanitária (ANVISA). Portaria $N^{\circ} 36,13$ De Janeiro De 1998. Alimentos À Base De Cereais Para Alimentação Infantil. Brasil: Diário Oficial da União (1998). Available at: http://bvsms.saude.gov.br/ bvs/saudelegis/anvisa/1998/prt0036_13_01_1998_rep.html.

57. European Union. Commission Directive 2006/125/EC of 5 December 2006 on Processed Cereal-Based Foods and Baby Foods for Infants and Young Children. Off J Eur Union (2006) L 339/:16.

58. Li Z, Jennings A. Worldwide Regulations of Standard Values of Pesticides for Human Health Risk Control: A Review. Int J Environ Res Public Health (2017) 14:826. doi: 10.3390/ijerph14070826

59. The Council of the European Union. Council Directive of 98/83/EC of 3 November 1998 on the Quality of Water Intended for Human Consumption. Off J Eur Communities (1998) L330:32-54.

60. Reynoso EC, Torres E, Bettazzi F, Palchetti I. Trends and Perspectives in Immunosensors for Determination of Currently-Used Pesticides: The Case of Glyphosate, Organophosphates, and Neonicotinoids. Biosensors (2019) 9:20. doi: 10.3390/bios9010020

61. Annett R, Habibi HR, Hontela A. Impact of Glyphosate and Glyphosate-Based Herbicides on the Freshwater Environment. J Appl Toxicol (2014) 34:458-79. doi: 10.1002/jat.2997

62. Matozzo V, Fabrello J, Marin MG. The Effects of Glyphosate and its Commercial Formulations to Marine Invertebrates: A Review. J Mar Sci Eng (2020) 8:399. doi: 10.3390/jmse8060399

63. Bonansea RI, Filippi I, Wunderlin DA, Marino DJG, Amé MV. The Fate of Glyphosate and AMPA in a Freshwater Endorheic Basin: An Ecotoxicological Risk Assessment. Toxics (2018) 6:3. doi: 10.3390/toxics6010003

64. Alonso LL, Demetrio PM, Agustina Etchegoyen M, Marino DJ. Glyphosate and Atrazine in Rainfall and Soils in Agroproductive Areas of the Pampas Region in Argentina. Sci Total Environ (2018) 645:89-96. doi: 10.1016/ j.scitotenv.2018.07.134

65. Anadón A, Martínez-Larrañaga MR, Martínez MA, Castellano VJ, Martínez M, Martin MT, et al. Toxicokinetics of Glyphosate and Its Metabolite Aminomethyl Phosphonic Acid in Rats. Toxicol Lett (2009) 190:91-5. doi: 10.1016/j.toxlet.2009.07.008

66. Brewster DW, Warren J, Hopkins WE. Metabolism of Glyphosate in SpragueDawley Rats: Tissue Distribution, Identification, and Quantitation of Glyphosate-Derived Materials Following a Single Oral Dose. Fundam Appl Toxicol (1991) 17:43-51. doi: 10.1016/0272-0590(91)90237-X

67. Davies D. Glyphosate Acid: Excretion and Tissue Retention of a Single Oral Dose $(1000 \mathrm{mg} / \mathrm{Kg})$ in the Rat, Unpublished report no CTL/P/4942. (1996). Zeneca Agrochemicals, Central Toxicology Laboratory, Alderley Park, Macclesfield, Cheshire, England. Submitted to WHO by Syngenta Crop Protection AG, Switzerland.

68. Davies D. Glyphosate Acid: Excretion and Tissue Retention of a Single Oral Dose $(10 \mathrm{Mg} / \mathrm{Kg})$ in the Rat. Unpublished report no CTL/P/4940. (1996).
Zeneca Agrochemicals, Central Toxicology Laboratory, Alderley Park, Macclesfield, Cheshire, England. Submitted to WHO by Syngenta Crop Protection AG, Switzerland.

69. Davies D. Glyphosate Acid: Excretion and Tissue Retention of a Single Oral Dose $(10 \mathrm{Mg} / \mathrm{Kg})$ in the Rat Following Repeat Dosing. Unpublished report no CTL/P/4944. (1996). Zeneca Agrochemicals, Central Toxicology Laboratory, Alderley Park, Macclesfield, Cheshire, England. Submitted to WHO by Syngenta Crop Protection AG, Switzerland.

70. Chan P, Mahler J. NTP Technical Report on the Toxicity Studies of Glyphosate (CAS No. 1071-83-6) Administered in Dosed Feed to F344/N Rats and B6C3F1 Mice. Toxic Rep Ser (1992) 16:1-D3.

71. Howe R, Chott R, McClanahan R. Metabolism of Glyphosate in SpagueDawley Rats. II. Identification, Characterization, and Quantitation of Glyphosate and Its Metabolites Following Intravenous and Oral Administration. Unpublished report (1988) Monsanto Environmental Health Laboratory, St. Louis, MO, USA.

72. Agency for Toxic Substances and Disease Registry (ATSDR). Toxicological Profile for Glyphosate. Atlanta, USA: Department of Health and Human Services, Public Health Service (2020). Available at: https://www.atsdr.cdc. gov/ToxProfiles/tp214.pdf.

73. Cho Y, Jeong W, Kim S, Choi H, You Y, Cho S, et al. Serial Measurement of Glyphosate Blood Concentration in a Glyphosate Potassium HerbicideIntoxicated Patient: A Case Report. Am J Emerg Med (2019) 37:e51600.e6:1600. doi: 10.1016/j.ajem.2019.04.042

74. Connolly A, Jones K, Basinas I, Galea KS, Kenny L, McGowan P, et al. Exploring the Half-Life of Glyphosate in Human Urine Samples. Int $J$ Hyg Environ Health (2019) 222:205-10. doi: 10.1016/j.ijheh.2018.09.004

75. Parvez S, Gerona RR, Proctor C, Friesen M, Ashby JL, Reiter JL, et al. Glyphosate Exposure in Pregnancy and Shortened Gestational Length: A Prospective Indiana Birth Cohort Study. Environ Health (2018) 17:23. doi: 10.1186/s12940-018-0367-0

76. Stajnko A, Tratnik JS, Kosjek T, Mazej D, Jagodic M, Erzen I, et al. Seasonal Glyphosate and AMPA Levels in Urine of Children and Adolescents Living in Rural Regions of Northeastern Slovenia. Environ Int (2020) 143:105985. doi: 10.1016/j.envint.2020.105985

77. Zhang F, Xu Y, Liu X, Pan L, Ding E, Dou J, et al. Concentration Distribution and Analysis of Urinary Glyphosate and its Metabolites in Occupationally Exposed Workers in Eastern China. Int J Environ Res Public Health (2020) 17:2943. doi: 10.3390/ijerph17082943

78. Kongtip P, Nankongnab N, Phupancharoensuk R, Palarach C, Sujirarat D, Sangprasert S, et al. Glyphosate and Paraquat in Maternal and Fetal Serums in Thai Women. J Agromedicine (2017) 22:282-9. doi: 10.1080/1059924X.2017. 1319315

79. Honeycutt Z, Rowlands H. Glyphosate Testing Full Report: Findings in American Mothers' Breast Milk, Urine and Water (2014). Available at: https://es.momsacrossamerica.com/glyphosate_testing_results (Accessed January 25, 2021).

80. Mcguire MK, Mcguire MA, Price WJ, Shafii B, Carrothers JM, Lackey KA, et al. Glyphosate and Aminomethylphosphonic Acid Are Not Detectable in Human Milk. Am J Clin Nutr (2016) 103:1285-90. doi: 10.3945/ ajcn.115.126854

81. Steinborn A, Alder L, Michalski B, Zomer P, Bendig P, Martinez SA, et al. Determination of Glyphosate Levels in Breast Milk Samples From Germany by LC-MS/MS and GC-MS/MS. J Agric Food Chem (2016) 64:1414-21. doi: $10.1021 /$ acs.jafc.5b05852

82. Gillezeau C, Van Gerwen M, Shaffer RM, Rana I, Zhang L, Sheppard L, et al. The Evidence of Human Exposure to Glyphosate: A Review. Environ Health (2019) 18:2. doi: 10.1186/s12940-018-0435-5

83. Mose T, Kjaerstad MB, Mathiesen L, Nielsen JB, Edelfors S, Knudsen LE. Placental Passage of Benzoic Acid, Caffeine, and Glyphosate in an Ex Vivo Human Perfusion System. J Toxicol Environ Health A (2008) 71:984-91. doi: 10.1080/01932690801934513

84. Poulsen MS, Rytting E, Mose T, Knudsen LE. Modeling Placental Transport: Correlation of In Vitro BeWo Cell Permeability and Ex Vivo Human Placental Perfusion. Toxicol In Vitro (2009) 23:1380-6. doi: 10.1016/j.tiv.2009.07.028

85. Valle AL, Mello FCC, Alves-Balvedi RP, Rodrigues LP, Goulart LR. Glyphosate Detection: Methods, Needs and Challenges. Environ Chem Lett (2019) 17:291-317. doi: 10.1007/s10311-018-0789-5 
86. Liao Y, Berthion JM, Colet I, Merlo M, Nougadère A, Hu R. Validation and Application of Analytical Method for Glyphosate and Glufosinate in Foods by Liquid Chromatography-Tandem Mass Spectrometry. J Chromatogr A (2018) 1549:31-8. doi: 10.1016/j.chroma.2018.03.036

87. Okada E, Coggan T, Anumol T, Clarke B, Allinson G. A Simple and Rapid Direct Injection Method for the Determination of Glyphosate and AMPA in Environmental Water Samples. Anal Bioanal Chem (2019) 411:715-24. doi: 10.1007/s00216-018-1490-z

88. Perry MJ, Mandrioli D, Belpoggi F, Manservisi F, Panzacchi S, Irwin C. Historical Evidence of Glyphosate Exposure From a US Agricultural Cohort. Environ Health (2019) 18:1-4. doi: 10.1186/s12940-019-0474-6

89. Nova P, Calheiros CS, Silva M. Glyphosate in Portuguese Adults - A Pilot Study. Environ Toxicol Pharmacol (2020) 80:103462. doi: 10.1016/ j.etap. 2020.103462

90. Rubio F, Veldhuis LJ, Clegg BS, Fleeker JR, Hall JC. Comparison of a Direct ELISA and an HPLC Method for Glyphosate Determinations in Water. J Agric Food Chem (2003) 51:691-6. doi: 10.1021/es8005207

91. Byer JD, Struger J, Klawunn P, Todd A, Sverko ED. Low Cost Monitoring of Glyphosate in Surface Waters Using the ELISA Method: An Evaluation. Environ Sci Technol (2008) 42:6052-7. doi: 10.1021/es8005207

92. González-Martínez MA, Brun EM, Puchades R, Maquieira Á, Ramsey K, Rubio F. Glyphosate Immunosensor. Application for Water and Soil Analysis. Anal Chem (2005) 77:4219-27. doi: 10.1021/ac048431d

93. Kiyama R, Wada-Kiyama Y. Estrogenic Endocrine Disruptors: Molecular Mechanisms of Action. Environ Int (2015) 83:11-40. doi: 10.1016/ j.envint.2015.05.012

94. Richard S, Moslemi S, Sipahutar H, Benachour N, Seralini G-E. Differential Effects of Glyphosate and Roundup on Human Placental Cells and Aromatase. Environ Health Perspect (2005) 113:716-20. doi: 10.1289/ehp.7728

95. Benachour N, Sipahutar H, Moslemi S, Gasnier C, Travert C, Séralini GE. Time- and Dose-Dependent Effects of Roundup on Human Embryonic and Placental Cells. Arch Environ Contam Toxicol (2007) 53:126-33. doi: 10.1007/ s00244-006-0154-8

96. Perego MC, Caloni F, Cortinovis C, Schutz LF, Albonico M, Tsuzukibashi D, et al. Influence of a Roundup Formulation on Glyphosate Effects on Steroidogenesis and Proliferation of Bovine Granulosa Cells In Vitro. Chemosphere (2017) 188:274-9. doi: 10.1016/j.chemosphere.2017.09.007

97. Thongprakaisang S, Thiantanawat A, Rangkadilok N, Suriyo T, Satayavivad J. Glyphosate Induces Human Breast Cancer Cells Growth Via Estrogen Receptors. Food Chem Toxicol (2013) 59:129-36. doi: 10.1016/ j.fct.2013.05.057

98. Mesnage R, Phedonos A, Biserni M, Arno M, Balu S, Corton JC, et al. Evaluation of Estrogen Receptor Alpha Activation by Glyphosate-Based Herbicide Constituents. Food Chem Toxicol (2017) 108:30-42. doi: 10.1016/ j.fct.2017.07.025

99. Gastiazoro M, Durando M, Milesi M, Lorenz V, Vollmer G, Varayoud J, et al. Glyphosate Induces Epithelial Mesenchymal Transition-Related Changes in Human Endometrial Ishikawa Cells via Estrogen Receptor Pathway. Mol Cell Endocrinol (2020) 510:110841. doi: 10.1016/j.mce.2020.110841

100. Bulun SE, Sebastian S, Takayama K, Suzuki T, Sasano H, Shozu M. The Human CYP19 (Aromatase P450) Gene: Update on Physiologic Roles and Genomic Organization of Promoters. J Steroid Biochem Molec Biol (2003) 86:219-24. doi: 10.1016/S0960-0760(03)00359-5

101. Carreau S. Germ Cells: A New Source of Estrogens in the Male Gonad. Mol Cell Endocrinol (2001) 178:65-72. doi: 10.1016/S0303-7207(01)00411-7

102. Gigante P, Berni M, Bussolati S, Grasselli F, Grolli S, Ramoni R, et al. Glyphosate Affects Swine Ovarian and Adipose Stromal Cell Functions. Anim Reprod Sci (2018) 195:185-96. doi: 10.1016/j.anireprosci.2018.05.023

103. Varayoud J, Durando M, Ramos J, Milesi MM, Ingaramo P, Muñoz de Toro M, et al. Effects of a Glyphosate-Based Herbicide on the Uterus of Adult Ovariectomized Rats. Environ Toxicol (2017) 32:1191-201. doi: 10.1002/ tox.22316

104. Guerrero Schimpf M, Milesi MM, Luque EH, Varayoud J. Glyphosate-Based Herbicide Enhances the Uterine Sensitivity to Estradiol in Rats. J Endocrinol (2018) 239:197-213. doi: 10.1530/JOE-18-0207

105. Sanderson P, Critchley H, Williams A, Arends M, Saunders P. New Concepts for an Old Problem: The Diagnosis of Endometrial Hyperplasia. Hum Reprod Update (2017) 23:232-54. doi: 10.1093/humupd/dmw042
106. Alarcón R, Rivera OE, Ingaramo PI, Tschopp MV, Dioguardi GH, Milesi MM, et al. Neonatal Exposure to a Glyphosate-Based Herbicide Alters the Uterine Differentiation of Prepubertal Ewe Lambs. Environ Pollut (2020) 265:114874. doi: 10.1016/j.envpol.2020.114874

107. Gomez A, Altamirano G, Leturia J, Bosquiazzo V, Muñoz De Toro M, Kass L. Male Mammary Gland Development and Methylation Status of Estrogen Receptor Alpha in Wistar Rats Are Modified by the Developmental Exposure to a Glyphosate-Based Herbicide. Mol Cell Endocrinol (2019) 481:14-25. doi: 10.1016/j.mce.2018.11.005

108. Rochester JR, Bolden AL. Bisphenol S and F: A Systematic Review and Comparison of the Hormonal Activity of Bisphenol A Substitute. Environ Health Perspect (2015) 123:643-50. doi: 10.1289/ehp.1408989

109. Practice Committee of the American Society for Reproductive Medicine. Diagnostic Evaluation of the Infertile Female: A Committee Opinion. Fertil Steril (2015) 103:e44-50. doi: 10.1016/j.fertnstert.2015.03.019

110. Inhorn MC, Patrizio P. Infertility Around the Globe: New Thinking on Gender, Reproductive Technologies and Global Movements in the 21st Century. Hum Reprod Update (2015) 21:411-26. doi: 10.1093/humupd/dmv016

111. Den Hond E, Tournaye H, De Sutter P, Ombelet W, Baeyens W, Covaci A, et al. Human Exposure to Endocrine Disrupting Chemicals and Fertility: A Case-Control Study in Male Subfertility Patients. Environ Int (2015) 84:154-60. doi: 10.1016/j.envint.2015.07.017

112. Ziv-Gal A, Flaws JA. Evidence for Bisphenol A-Induced Female Infertility: A Review (2007-2016). Fertil Steril (2016) 106:827-56. doi: 10.1016/ j.fertnstert.2016.06.027

113. Chiu YH, Afeiche MC, Gaskins AJ, Williams PL, Petrozza JC, Tanrikut C, et al. Fruit and Vegetable Intake and Their Pesticide Residues in Relation to Semen Quality Among Men From a Fertility Clinic. Hum Reprod (2015) 30:1342-51. doi: 10.1093/humrep/dev064

114. Chiu YH, Williams PL, Gillman MW, Gaskins AJ, Mínguez-Alarcón L, Souter I, et al. Association Between Pesticide Residue Intake From Consumption of Fruits and Vegetables and Pregnancy Outcomes Among Women Undergoing Infertility Treatment With Assisted Reproductive Technology. JAMA Intern Med (2018) 178:17-26. doi: 10.1001/ jamainternmed.2017.5038

115. Mostafalou S, Abdollahi M. Pesticides: An Update of Human Exposure and Toxicity. Arch Toxicol (2017) 91:549-99. doi: 10.1007/s00204-016-1849-x

116. García J, Ventura MI, Requena M, Hernández AF, Parrón T, Alarcón R. Association of Reproductive Disorders and Male Congenital Anomalies With Environmental Exposure to Endocrine Active Pesticides. Reprod Toxicol (2017) 71:95-100. doi: 10.1016/j.reprotox.2017.04.011

117. Rappazzo KM, Warren JL, Davalos AD, Meyer RE, Sanders AP, Brownstein NC, et al. Maternal Residential Exposure to Specific Agricultural Pesticide Active Ingredients and Birth Defects in a 2003-2005 North Carolina Birth Cohort. Birth Defects Res (2019) 111:312-23. doi: 10.1002/bdr2.1448

118. Razi S, Rezaeian M, Dehkordi FG, Manshoori A, Goujani R, Vazirinejad R. Exposure to Pistachio Pesticides and Stillbirth: A Case-Control Study. Epidemiol Health (2016) 38:e2016016. doi: 10.4178/epih.e2016016

119. Suhl J, Romitti PA, Rocheleau C, Cao Y, Burns TL, Conway K, et al. Parental Occupational Pesticide Exposure and Nonsyndromic Orofacial Clefts. J Occup Environ Hyg (2018) 15:641-53. doi: 10.1080/15459624.2018.1484127

120. Arbuckle TE, Lin Z, Mery LS. An Exploratory Analysis of the Effect of Pesticide Exposure on the Risk of Spontaneous Abortion in an Ontario Farm Population. Environ Health Perspect (2001) 109:851-7. doi: 10.1289/ ehp.01109851

121. Milesi MM, Lorenz V, Pacini G, Repetti MR, Demonte LD, Varayoud J, et al. Perinatal Exposure to a Glyphosate-Based Herbicide Impairs Female Reproductive Outcomes and Induces Second-Generation Adverse Effects in Wistar Rats. Arch Toxicol (2018) 92:2629-43. doi: 10.1007/s00204-0182236-6

122. Milesi MM, Lorenz V, Beldomenico PM, Vaira S, Varayoud J, Luque EH. Response to Comments on: Perinatal Exposure to a Glyphosate-Based Herbicide Impairs Female Reproductive Outcomes and Induces SecondGeneration Adverse Effects in Wistar Rats. Arch Toxicol (2019) 93:3635-8. doi: 10.1007/s00204-019-02609-0

123. Dallegrave E, Mantese FD, Coelho RS, Pereira JND, Dalsenter PR, Langeloh A. The Teratogenic Potential of the Herbicide Glyphosate-Roundup ${ }^{\circledR}$ in Wistar Rats. Toxicol Lett (2003) 142:45-52. doi: 10.1016/S0378-4274(02)00483-6 
124. EPA. Glyphosat. Dietary Exposure Analysis in Support of Registration Review (2017). Available at: https://www.regulations.gov/document?D=EPA-HQOPP-2009-0361-0071 (Accessed 26 April, 2021).

125. EFSA. Conclusion on the Peer Review of the Pesticide Risk Assessment of the Active Substance Glyphosate. EFSA J (2015) 13:4302. doi: 10.2903/ j.efsa.2015.4302

126. Panzacchi S, Mandrioli D, Manservisi F, Bua L, Falcioni L, Spinaci M, et al. The Ramazzini Institute 13-Week Study on Glyphosate-Based Herbicides at Human-Equivalent Dose in Sprague Dawley Rats: Study Design and First inLife Endpoints Evaluation. Environ Health (2018) 17:52. doi: 10.1186/ s12940-018-0393-y

127. Ingaramo PI, Guerrero Schimpf M, Milesi MM, Luque EH, Varayoud J. Acute Uterine Effects and Long- Term Reproductive Alterations in Postnatally Exposed Female Rats to a Mixture of Commercial Formulations of Endosulfan and Glyphosate. Food Chem Toxicol (2019) 134:110832. doi: 10.1016/j.fct.2019.110832

128. Almeida LL, Teixeira ÁAC, Soares AF, Cunha FMD, Silva VAD Júnior, Vieira Filho LD, et al. Effects of Melatonin in Rats in the Initial Third Stage of Pregnancy Exposed to Sub-Lethal Doses of Herbicides. Acta Histochem (2017) 119:220-7. doi: 10.1016/j.acthis.2017.01.003

129. Hamdaoui L, Naifar M, Rahmouni F, Harrabi B, Ayadi F, Sahnoun Z, et al. Subchronic Exposure to Kalach 360 SL-Induced Endocrine Disruption and Ovary Damage in Female Rats. Arch Physiol Biochem (2018) 124:27-34. doi: 10.1080/13813455.2017.1352606

130. Varayoud J, Ramos JG, Muñoz de Toro M, Luque EH. Long-Lasting Effects of Neonatal Bisphenol A Exposure on the Implantation Process. Vitam Horm (2014) 94:253-75. doi: 10.1016/B978-0-12-800095-3.00010-9

131. Fatemi HM, Popovic-Todorovic B. Implantation in Assisted Reproduction: A Look at Endometrial Receptivity. Reprod BioMed Online (2013) 27:530-8. doi: 10.1016/j.rbmo.2013.05.018

132. Vasquez YM, DeMayo FJ. Role of Nuclear Receptors in Blastocyst Implantation. Semin Cell Dev Biol (2013) 24:724-35. doi: 10.1016/ j.semcdb.2013.08.004

133. Lessey BA, Young SL. Structure, Function, and Evaluation of the Female Reproductive Tract. In: Yen and Jaffe's Reproductive Endocrinology, eighth ed. Philadelphia, USA: Elsevier (2019).

134. Tranguch S, Daikoku T, Guo Y, Wang H, Dey SK. Molecular Complexity in Establishing Uterine Receptivity and Implantation. Cell Mol Life Sci (2005) 62:1964-73. doi: 10.1007/s00018-005-5230-0

135. Ma W-G, Song H, Das SK, Paria BC, Dey SK. Estrogen Is a Critical Determinant That Specifies the Duration of the Window of Uterine Receptivity for Implantation. Proc Natl Acad Sci USA (2003) 100:2963-8. doi: 10.1073/pnas.0530162100

136. Robertshaw I, Bian F, Das SK. Mechanisms of Uterine Estrogen Signaling During Early Pregnancy in Mice: An Update. J Mol Endocrinol (2016) 56: R127-38. doi: 10.1530/JME-15-0300

137. Gasnier C, Dumont C, Benachour N, Clair E, Chagnon M-C, Seralini G-E. Glyphosate-Based Herbicides Are Toxic and Endocrine Disruptors in Human Cell Lines. Toxicology (2009) 262:184-91. doi: 10.1016/j.tox.2009.06.006

138. Arslan M, Bocca S, Arslan EO, Duran HE, Stadtmauer L, Oehninger S. Cumulative Exposure to High Estradiol Levels During the Follicular Phase of IVF Cycles Negatively Affects Implantation. J Assist Reprod Genet (2007) 24:111-7. doi: 10.1007/s10815-006-9101-x

139. Modi D, Godbole G. HOXA10 Signals on the Highway Through Pregnancy. J Reprod Immunol (2009) 83:72-8. doi: 10.1016/j.jri.2009.07.009

140. Salleh N, Giribabu N. Leukemia Inhibitory Factor: Roles in Embryo Implantation and in Nonhormonal Contraception. Sci World J (2014) 2014:201514. doi: 10.1155/2014/201514

141. Rosario GX, Stewart CL. The Multifaceted Actions of Leukaemia Inhibitory Factor in Mediating Uterine Receptivity and Embryo Implantation. Am J Reprod Immunol (2016) 75:246-55. doi: 10.1111/aji.12474

142. Bagot CN, Kliman HJ, Taylor HS. Maternal HOXA10 Is Required for Pinopod Formation in the Development of Mouse Uterine Receptivity to Embryo Implantation. Dev Dyn (2001) 222:538-44. doi: 10.1002/dvdy.1209

143. Cheng JG, Chen JR, Hernandez L, Alvord WG, Stewart CL. Dual Control of LIF Expression and LIF Receptor Function Regulate Stat3 Activation at the Onset of Uterine Receptivity and Embryo Implantation. Proc Natl Acad Sci USA (2001) 98:8680-5. doi: 10.1073/pnas.151180898
144. Rosario GX, Hondo E, Jeong JW, Mutalif R, Ye X, Yee LX, et al. The LIFMediated Molecular Signature Regulating Murine Embryo Implantation. Biol Reprod (2011) 91:66. doi: 10.1095/biolreprod.114.118513

145. Satokata I, Benson G, Maas R. Sexually Dimorphic Sterility Phenotypes in HOXA10-Deficient Mice. Nature (1995) 374:460-3. doi: 10.1038/374460a0

146. Stewart CL, Kaspar P, Brunet LJ, Bhatt H, Gadi I, Kontgen F, et al. Blastocyst Implantation Depends on Maternal Expression of Leukaemia Inhibitory Factor. Nature (1992) 359:76-9. doi: 10.1038/359076a0

147. Wang TS, Gao F, Qi QR, Qin FN, Zuo RJ, Li ZL, et al. Dysregulated LIFSTAT3 Pathway Is Responsible for Impaired Embryo Implantation in a Streptozotocin-Induced Diabetic Mouse Model. Biol Open (2015) 4:893-902. doi: $10.1242 /$ bio. 011890

148. Choi Y, Kim HR, Lim EJ, Park M, Yoon JA, Kim YS, et al. Integrative Analyses of Uterine Transcriptome and microRNAome Reveal Compromised LIF-STAT3 Signaling and Progesterone Response in the Endometrium of Patients With Recurrent/Repeated Implantation Failure (RIF). PloS One (2016) 11:e0157696. doi: 10.1371/journal.pone.0157696

149. Kara M, Ozcan SS, Aran T, Kara O, Yilmaz N. Evaluation of Endometrial Receptivity by Measuring HOXA-10, HOXA-11, and Leukemia Inhibitory Factor Expression in Patients With Polycystic Ovary Syndrome. Gynecol Minim Invasive Ther (2019) 8:118-22. doi: 10.4103/GMIT.GMIT_112_18

150. Margioula-Siarkou C, Prapas Y, Petousis S, Milias S, Ravanos K, Dagklis T, et al. LIF Endometrial Expression Is Impaired in Women With Unexplained Infertility While LIF-R Expression in All Infertility Sub-Groups. Cytokine (2017) 96:166-72. doi: 10.1016/j.cyto.2017.04.009

151. Nazarenko TA, Kalinina EA, Knyazeva EA, Kiselev VI, Smolnikova VY, Sukhikh GT. The Role of Abnormal Hypermethylation of the HOXA10 and HOXA11 Promoters in Implantation Failures in IVF Programs. Gynecol Endocrinol (2019) 35:31-4. doi: 10.1080/09513590.2019.1632087

152. Szczepańska M, Wirstlein P, Luczak M, Jagodziński PP, Skrzypczak J. Reduced Expression of HOXA10 in the Midluteal Endometrium From Infertile Women With Minimal Endometriosis. BioMed Pharmacother (2010) 64:697-705. doi: 10.1016/j.biopha.2010.09.012

153. Skinner MK, Guerrero-Bosagna C, Haque M, Nilsson E, Bhandari R, McCarrey JR. Environmentally Induced Transgenerational Epigenetic Reprogramming of Primordial Germ Cells and the Subsequent Germ Line. PloS One (2013) 8:e66318. doi: 10.1371/journal.pone.0066318

154. Agrawal A, Murphy RF, Agrawal DK. DNA Methylation in Breast and Colorectal Cancers. Mod Pathol (2007) 20:711-21. doi: 10.1038/ modpathol.3800822

155. Asada H, Yamagata Y, Taketani T, Matsuoka A, Tamura H, Hattori N, et al. Potential Link Between Estrogen Receptor-Alpha Gene Hypomethylation and Uterine Fibroid Formation. Mol Hum Reprod (2008) 14:539-45. doi: 10.1093/molehr/gan045

156. Hagrass HA, Pasha HF, Ali AM. Estrogen Receptor Alpha (ERalpha) Promoter Methylation Status in Tumor and Serum DNA in Egyptian Breast Cancer Patients. Gene (2014) 552:81-6. doi: 10.1016/j.gene.2014.09.016

157. Maekawa R, Mihara Y, Sato S, Okada M, Tamura I, Shinagawa M, et al. Aberrant DNA Methylation Suppresses Expression of Estrogen Receptor 1 (ESR1) in Ovarian Endometrioma. J Ovarian Res (2019) 12:14. doi: 10.1186/ s13048-019-0489-1

158. Kwiatkowska M, Reszka E, Woźniak K, Jabłońska E, Michałowicz J, Bukowska B. DNA Damage and Methylation Induced by Glyphosate in Human Peripheral Blood Mononuclear Cells (In Vitro Study). Food Chem Toxicol (2017) 105:93-8. doi: 10.1016/j.fct.2017.03.051

159. Woźniak E, Reszka E, Jabłońska E, Balcerczyk A, Broncel M, Bukowska B. Glyphosate Affects Methylation in the Promoter Regions of Selected Tumor Suppressors as Well as Expression of Major Cell Cycle and Apoptosis Drivers in PBMCs (In Vitro Study). Toxicol In Vitro (2020) 63:104736. doi: 10.1016/ j.tiv.2019.104736

160. Ji H, Xu L, Wang Z, Fan X, Wu L. Differential microRNA Expression in the Prefrontal Cortex of Mouse Offspring Induced by Glyphosate Exposure During Pregnancy and Lactation. Exp Ther Med (2018) 15:2457-67. doi: 10.3892/etm.2017.5669

161. Yu N, Tong Y, Zhang D, Zhao S, Fan X, Wu L, et al. Circular RNA Expression Profiles in Hippocampus From Mice With Perinatal Glyphosate Exposure. Biochem Biophys Res Commun (2018) 501:838-45. doi: 10.1016/ j.bbrc.2018.04.200 
162. Carvalho S, Freitas M, Antunes L, Monteiro-Reis S, Vieira-Coimbra M, Tavares A, et al. Prognostic Value of Histone Marks H3K27me3 and H3K9me3 and Modifying Enzymes EZH2, SETDB1 and LSD-1 in Colorectal Cancer. J Cancer Res Clin Oncol (2018) 144:2127-37. doi: 10.1007/s00432-018-2733-2

163. Reddy KB. MicroRNA (miRNA) in Cancer. Cancer Cell Int (2015) 15:38. doi: 10.1186/s12935-015-0185-1

164. Ilie IR, Georgescu CE. Polycystic Ovary Syndrome-Epigenetic Mechanisms and Aberrant microRNA. Adv Clin Chem (2015) 71:25-45. doi: 10.1016/ bs.acc.2015.06.001

165. Revel A, Achache H, Stevens J, Smith Y, Reich R. MicroRNAs Are Associated With Human Embryo Implantation Defects. Hum Reprod (2011) 26:283040. doi: 10.1093/humrep/der255

166. Li X, Xiao B, Chen XS. DNA Methylation: A New Player in Multiple Sclerosis. Mol Neurobiol (2017) 54:4049-59. doi: 10.1007/s12035-0169966-3

167. Silva JN DA, Monteiro NR, Antunes PA, Favareto APA. Maternal and Developmental Toxicity After Exposure to Formulation of Chlorothalonil and Thiophanate-Methyl During Organogenesis in Rats. Acad Bras Cienc (2020) 92:e20191026. doi: 10.1590/0001-3765202020191026

168. Zhang J-Y, Dai H-X, Wu Q-J, Li J, Huang Y-H, Chen Z-J, et al. Maternal Exposure to Ambient Levels of Sulfur Dioxide and Risk of Neural Tube Defects in 14 Cities in Liaoning Province, China: A Population-Based CaseControl Study. J Expo Sci Environ Epidemiol (2021) 2:266-75. doi: 10.1038/ s41370-020-00273-6

169. Choi H, Wang L, Lin X, Spengler JD, Perera FP. Fetal Window of Vulnerability to Airborne Polycyclic Aromatic Hydrocarbons on Proportional Intrauterine Growth Restriction. PloS One (2012) 7:e35464. doi: 10.1371/journal.pone. 0035464

170. Spinder N, Prins JR, Bergman JEH, Smidt N, Kromhout H, Boezen HM, et al. Congenital Anomalies in the Offspring of Occupationally Exposed Mothers: A Systematic Review and Meta-Analysis of Studies Using Expert Assessment for Occupational Exposures. Hum Reprod (2019) 34:903-19. doi: 10.1093/ humrep/dez033

171. Toichuev RM, Zhilova LV, Paizildaev TR, Khametova MS, Rakhmatillaev A, Sakibaev KS, et al. Organochlorine Pesticides in Placenta in Kyrgyzstan and the Effect on Pregnancy, Childbirth, and Newborn Health. Environ Sci Pollut Res Int (2018) 25:31885-94. doi: 10.1007/s11356-017-0962-6

172. Baxter FA, Drake AJ. Non-Genetic Inheritance Via the Male Germline in Mammals. Philos Trans R Soc Lond B Biol Sci (2019) 374:20180118. doi: 10.1098/rstb.2018.0118

173. Manservisi F, Lesseur C, Panzacchi S, Mandrioli D, Falcioni L, Bua L, et al. The Ramazzini Institute 13-Week Pilot Study Glyphosate-Based Herbicides Administered at Human-Equivalent Dose to Sprague Dawley Rats: Effects on Development and Endocrine System. Environ Health (2019) 18:15. doi: 10.1186/s12940-019-0453-y

174. Ren X, Dai P, Perveen A, Tang Q, Zhao L, Jia X, et al. Effects of Chronic Glyphosate Exposure to Pregnant Mice on Hepatic Lipid Metabolism in Offspring. Environ Pollut (2019) 254:112906. doi: 10.1016/j.envpol. 2019.07.074

175. Gallegos CE, Bartos M, Bras C, Gumilar F, Antonelli MC, Minetti A. Exposure to a Glyphosate-Based Herbicide During Pregnancy and Lactation Induces Neurobehavioral Alterations in Rat Offspring. Neurotoxicology (2016) 53:20-8. doi: 10.1016/j.neuro.2015.11.015

176. Gallegos CE, Baier CJ, Bartos M, Bras C, Domínguez S, Mónaco N, et al. Perinatal Glyphosate-Based Herbicide Exposure in Rats Alters Brain Antioxidant Status, Glutamate and Acetylcholine Metabolism and Affects Recognition Memory. Neurotox Res (2018) 34:363-74. doi: 10.1007/s12640018-9894-2

177. Ait-Bali Y, Ba-M'hamed S, Gambarotta G, Sassoè-Pognetto M, Giustetto M, Bennis M. Pre- and Postnatal Exposure to Glyphosate-Based Herbicide Causes Behavioral and Cognitive Impairments in Adult Mice: Evidence of Cortical Ad Hippocampal Dysfunction. Arch Toxicol (2020) 94:1703-23. doi: 10.1007/s00204-020-02677-7

178. Coullery R, Pacchioni AM, Rosso SB. Exposure to Glyphosate During Pregnancy Induces Neurobehavioral Alterations and Downregulation of Wnt5a-CaMKII Pathway. Reprod Toxicol (2020) 96:390-8. doi: 10.1016/ j.reprotox.2020.08.006
179. de Souza JS, Laureano-Melo R, Herai RH, Da Conceição RR, Oliveira KC, Da Silva IDCG, et al. Maternal Glyphosate-Based Herbicide Exposure Alters Antioxidant-Related Genes in the Brain and Serum Metabolites of Male Rat Offspring. Neurotoxicology (2019) 74:121-31. doi: 10.1016/j.neuro. 2019.06.004

180. Pu Y, Yang J, Chang L, Qu Y, Wang S, Zhang K, et al. Maternal Glyphosate Exposure Causes Autism-Like Behaviors in Offspring Through Increased Expression of Soluble Epoxide Hydrolase. Proc Natl Acad Sci USA (2020) 117:11753. doi: 10.1073/pnas.1922287117

181. Drake AJ, Liu L, Kerrigan D, Meehan RR, Seckl JR. Multigenerational Programming in the Glucocorticoid Programmed Rat Is Associated With Generation-Specific and Parent of Origin Effects. Epigenetics (2011) 6:133443. doi: 10.4161/epi.6.11.17942

182. Richards M, Hardy R, Kuh D, Wadsworth MEJ. Birthweight, Postnatal Growth and Cognitive Function in a National UK Birth Cohort. Int J Epidemiol (2002) 31:342-8. doi: 10.1093/ije/31.2.342

183. Barker DJ. The Developmental Origins of Chronic Adult Disease. Acta Paediatr (2004) 93:26-33. doi: 10.1111/j.1651-2227.2004.tb00236.x

184. Demelash H, Motbainor A, Nigatu D, Gashaw K, Melese A. Risk Factors for Low Birth Weight in Bale Zone Hospitals, South-East Ethiopia : A CaseControl Study. BMC Pregnancy Childbirth (2015) 15:264. doi: 10.1186/ s12884-015-0677-y

185. Mu M, Wang S-F, Sheng J, Zhao Y, Li H-Z, Hu C-L, et al. Birth Weight and Subsequent Blood Pressure: A Meta-Analysis. Arch Cardiovasc Dis (2012) 105:99-113. doi: 10.1016/j.acvd.2011.10.006

186. Lopez-Espinosa M-J, Murcia M, Iñiguez C, Vizcaino E, Costa O, FernándezSomoano A, et al. Organochlorine Compounds and Ultrasound Measurements of Fetal Growth in the INMA Cohort (Spain). Environ Health Perspect (2016) 124:157-63. doi: 10.1289/ehp.1408907

187. Ferguson KK, van den Dries MA, Gaillard R, Pronk A, Spaan S, Tiemeier H, et al. Organophosphate Pesticide Exposure in Pregnancy in Association With Ultrasound and Delivery Measures of Fetal Growth. Environ Health Perspect (2019) 127:087005. doi: 10.1289/EHP4858

188. Sathyanarayana S, Basso O, Karr CJ, Lozano P, Alavanja M, Sandler DP, et al. Maternal Pesticide Use and Birth Weight in the Agricultural Health Study. J Agromedicine (2010) 15:127-36. doi: 10.1080/10599241003622699

189. Snijder CA, Roeleveld N, Velde E, Steegers EAP, Raat H, Hofman A, et al. Occupational Exposure to Chemicals and Fetal Growth: The Generation R Study. Hum Reprod (2012) 27:910-20. doi: 10.1093/humrep/der437

190. Whyatt Robin M, Rauh V, Barr Dana B, Camann David E, Andrews Howard F, Garfinkel R, et al. Prenatal Insecticide Exposures and Birth Weight and Length Among an Urban Minority Cohort. Environ Health Perspect (2004) 112:1125-32. doi: 10.1289/ehp.6641

191. Risnes KR, Romundstad PR, Nilsen TIL, Eskild A, Vatten LJ. Placental Weight Relative to Birth Weight and Long-Term Cardiovascular Mortality: Findings From a Cohort of 31,307 Men and Women. Am J Epidemiol (2009) 170:622-31. doi: 10.1093/aje/kwp182

192. Fowden AL, Sferruzzi-Perri AN, Coan PM, Constancia M, Burton GJ. Placental Efficiency and Adaptation: Endocrine Regulation. J Physiol (2009) 587:3459-72. doi: 10.1113/jphysiol.2009.173013

193. Sibley CP, Brownbill P, Dilworth M, Glazier JD. Review: Adaptation in Placental Nutrient Supply to Meet Fetal Growth Demand: Implications for Programming. Placenta (2010) 31:S70-4. doi: 10.1016/j.placenta.2009.12.020

194. Macdonald EM, Natale R, Regnault TRH, Koval JJ, Campbell MK. Obstetric Conditions and the Placental Weight Ratio. Placenta (2014) 35:582-6. doi: 10.1016/j.placenta.2014.04.019

195. Barker DJ, Osmond C, Golding J, Kuh D, Wadsworth ME. Growth in Utero, Blood Pressure in Childhood and Adult Life, and Mortality From Cardiovascular Disease. BMJ (1989) 298:564. doi: 10.1136/bmj.298.6673.564

196. Barker DJP, Godfrey KM, Gluckman PD, Harding JE, Owens JA, Robinson JS. Fetal Nutrition and Cardiovascular Disease in Adult Life. Lancet (1993) 341:938-41. doi: 10.1016/0140-6736(93)91224-A

197. Londero AP, Bertozzi S, Visentin S, Fruscalzo A, Driul L, Marchesoni D. High Placental Index and Poor Pregnancy Outcomes: A Retrospective Study of 18386 Pregnancies. Gynecol Endocrinol (2013) 29:666-9. doi: 10.3109/ 09513590.2013.798273

198. Camacho JA, Allard P. Chapter 4-1. Germline and Transgenerational Impacts of Toxicant Exposures. In: SD McCullough and DC Dolinoy, 
editors. Toxicoepigenetics: Core Principles and Applications. Academic Press (2019) 251-63. doi: 10.1016/B978-0-12-812433-8.00011-3

199. Herek JS, Vargas L, Trindade SAR, Rutkoski CF, Macagnan N, Hartmann PA, et al. Can Environmental Concentrations of Glyphosate Affect Survival and Cause Malformation in Amphibians? Effects From a Glyphosate-Based Herbicide on Physalaemus Cuvieri and P. Gracilis (Anura: Leptodactylidae). Environ Sci Pollut Res Int (2020) 27:22619-30. doi: 10.1007/s11356-020-08869-z

200. Paganelli A, Gnazzo V, Acosta H, López SL, Carrasco AE. Glyphosate-Based Herbicides Produce Teratogenic Effects on Vertebrates by Impairing Retinoic Acid Signaling. Chem Res Toxicol (2010) 23:1586-95. doi: 10.1021/tx1001749

201. Roy NM, Carneiro B, Ochs J. Glyphosate Induces Neurotoxicity in Zebrafish. Environ Toxicol Pharmacol (2016) 42:45-54. doi: 10.1016/j.etap.2016.01.003

202. Williams GM, Kroes R, Munro IC. Safety Evaluation and Risk Assessment of Herbicide Roundup and Its Active Ingredient, Glyphosate, for Humans. Regul Toxicol Pharmacol (2000) 31:117-65. doi: 10.1006/rtph.1999.1371

203. Mostafalou S, Abdollahi M. The Link of Organophosphorus Pesticides With Neurodegenerative and Neurodevelopmental Diseases Based on Evidence and Mechanisms. Toxicology (2018) 409:44-52. doi: 10.1016/j.tox.2018.07.014

204. Richardson JR, Roy A, Shalat SL, Von Stein RT, Hossain MM, Buckley B, et al. Elevated Serum Pesticide Levels and Risk for Alzheimer Disease. JAMA Neurol (2014) 71:284-90. doi: 10.1001/jamaneurol.2013.6030

205. Saeedi Saravi SS, Dehpour AR. Potential Role of Organochlorine Pesticides in the Pathogenesis of Neurodevelopmental, Neurodegenerative, and Neurobehavioral Disorders: A Review. Life Sci (2016) 145:255-64. doi: 10.1016/j.lfs.2015.11.006

206. Barbosa ER, Leiros Da Costa MD, Bacheschi LA, Scaff M, Leite CC. Parkinsonism After Glycine-Derivate Exposure. Mov Disord (2001) 16:565-8. doi: 10.1002/mds.1105

207. Wang G, Fan X-N, Tan Y-Y, Cheng Q, Chen S-D. Parkinsonism After Chronic Occupational Exposure to Glyphosate. Parkinsonism Relat Disord (2011) 17:486-7. doi: 10.1016/j.parkreldis.2011.02.003

208. von Ehrenstein OS, Ling C, Cui X, Cockburn M, Park AS, Yu F, et al. Prenatal and Infant Exposure to Ambient Pesticides and Autism Spectrum Disorder in Children: Population Based Case-Control Study. BMJ (2019) 364:1962. doi: $10.1136 /$ bmj.1962

209. Martínez M-A, Rodríguez J-L, Lopez-Torres B, Martínez M, MartínezLarrañaga M-R, Maximiliano J-E, et al. Use of Human Neuroblastoma SH-SY5Y Cells to Evaluate Glyphosate-Induced Effects on Oxidative Stress, Neuronal Development and Cell Death Signaling Pathways. Environ Int (2020) 135:105414. doi: 10.1016/j.envint.2019.105414

210. Pu Y, Chang L, Qu Y, Wang S, Tan Y, Wang X, et al. Glyphosate Exposure Exacerbates the Dopaminergic Neurotoxicity in the Mouse Brain After
Repeated Administration of MPTP. Neurosci Lett (2020) 730:135032. doi: 10.1016/j.neulet.2020.135032

211. Cattani D, De Liz Oliveira Cavalli VL, Heinz Rieg CE, Domingues JT, DalCim T, Tasca CI, et al. Mechanisms Underlying the Neurotoxicity Induced by Glyphosate-Based Herbicide in Immature Rat Hippocampus: Involvement of Glutamate Excitotoxicity. Toxicology (2014) 320:34-45. doi: 10.1016/j.tox.2014.03.001

212. Argou-Cardozo I, Zeidán-Chuliá F. Clostridium Bacteria and Autism Spectrum Conditions: A Systematic Review and Hypothetical Contribution of Environmental Glyphosate Levels. Med Sci (2018) 6:29. doi: 10.3390/ medsci6020029

213. Mcbirney M, King SE, Pappalardo M, Houser E, Unkefer M, Nilsson E, et al. Atrazine Induced Epigenetic Transgenerational Inheritance of Disease, Lean Phenotype and Sperm Epimutation Pathology Biomarkers. PloS One (2017) 12:e0184306. doi: 10.1371/journal.pone.0184306

214. Hartung T. Thoughts on Limitations of Animal Models. Parkinsonism Relat Disord (2008) 14:S81-83. doi: 10.1016/j.parkreldis.2008.04.003

215. Vandenberg LN, Blumberg B, Antoniou MN, Benbrook CM, Carroll L, Colborn T, et al. Is It Time to Reassess Current Safety Standards for Glyphosate-Based Herbicides? J Epidemiol Community Health (2017) 71:613-8. doi: 10.1136/jech-2016-208463

216. Beckie HJ, Flower KC, Ashworth MB. Farming Without Glyphosate? Plants (2020) 9:96. doi: 10.3390/plants9010096

217. Reboud X, Blanck M, Aubertot J, Jeuffroy M, Munier-Jolain N, ThiolletScholtus M. Uses and Alternatives to Glyphosate in French Agriculture. France: INRA (2017). Report TR507024.

218. Fogliatto S, Ferrero A, Vidotto F. Chapter Six - Current and Future Scenarios of Glyphosate Use in Europe: Are There Alternatives? In: DL Sparks, editor. Advances in Agronom. Academic Press (2020) 63:219-78. doi: 10.1016/ bs.agron.2020.05.005

Conflict of Interest: The authors declare that the research was conducted in the absence of any commercial or financial relationships that could be construed as a potential conflict of interest.

Copyright $\odot 2021$ Milesi, Lorenz, Durando, Rossetti and Varayoud. This is an openaccess article distributed under the terms of the Creative Commons Attribution License (CC BY). The use, distribution or reproduction in other forums is permitted, provided the original author(s) and the copyright owner(s) are credited and that the original publication in this journal is cited, in accordance with accepted academic practice. No use, distribution or reproduction is permitted which does not comply with these terms. 